\title{
Öğretmenlerin Mesleki Yeterliklerini Etkileyen Faktörler
}

\author{
Emin Tamer YENEN ${ }^{1}$ \\ $\ddot{O} z$
}

$\mathrm{Bu}$ araştırmanın amac1, öğretmenlerin meslekî yeterliklerini etkileyen faktörleri belirlemek ve öğretmenlerin meslekî yeterliklerini arttırabilmeler için öneriler geliştirebilmektir. Araştırma nitel araştırma modellerinden olan durum çalışması çerçevesinde yürütülmüştür. Araştırmanın çalışma grubunu 2019-2020 eğitim-öğretim yılında Aksaray, Kayseri ve Nevşehir illerinde farklı branşlarda görev yapan gönüllü 20 öğretmen oluşturmaktadır. Katılımcıların belirlenmesinde kolay ulaşılabilir durum örneklemesi kullanılmıştır. Çalışmada veri toplama aracı olarak yarı yapılandırılmış görüşme formu kullanılmıştır. Araştırmacı tarafından geliştirilen form öğretmenlerin mesleki yeterliklerini etkileyen faktörlere ilişkin düşüncelerini açığa çıkaran açık uçlu sekiz sorudan oluşmuştur. Araştırmanın verileri içerik analizi yöntemi kullanılarak analiz edilmiştir. Elde edilen verilerin çözümlenmesinde bilgisayar destekli nitel veri analizi programı kullanılmıştır. Çalışmada öğretmenlerin genel anlamda mesleki yeterliklerini etkileyen faktörler; hizmet öncesi eğitim, mesleğe karşı tutum, okul iklimi, mesleki deneyim, mesleki gelişim, aile ve sosyal çevre ve ekonomik durum olarak belirlenmiştir. Sonuç olarak, öğretmenlerin mesleki yeterliklerini sağlamaya yönelik mesleki gelişim planlamalarının yapılmasına ihtiyaç olduğu söylenebilir. Bu bağlamda, öğretmenlerin mesleki yeterliklerini arttırmak için kapsamlı ve sürekli mesleki gelişim programları hazırlanarak uygulamaya konulabilir.

Anahtar Kelimeler: Öğretmen, Öz Yeterlik, Mesleki Yeterlik, Öğretmen Yeterlikleri

\section{Factors Affecting Teachers' Professional Competencies}

\begin{abstract}
The purpose of this study is to determine the factors affecting teachers' professional competencies and to develop suggestions for teachers to increase their professional competencies. The research was carried out within the framework of the case study, which is one of the qualitative research models. The study group of the research consists of 20 volunteer teachers working in different branches in the provinces Aksaray, Kayseri and Nevşehir in the 2019-2020 academic year. Convenience sampling was used to identify the participants. In the study, a semistructured interview form was used as a data collection tool. The form developed by the researcher consisted of eight open-ended questions that reveal teachers' thoughts on factors affecting their professional competence. The data of the research were analyzed by using content analysis method. A computer-aided qualitative data analysis program was used to analyze the obtained data. Factors affecting teachers' professional competencies in general terms were found as; pre-service education, attitude towards the profession, school climate, professional experience, professional development, family and social environment and economic situation. As a result, it can be said that there is a need to make professional development plans to provide teachers' professional competencies. In this context, comprehensive and continuous professional development programs can be prepared and implemented in order to increase the professional competencies of teachers.
\end{abstract}

Key Words: Teacher, Self-Efficacy, Professional Competence, Teacher Competencies

\section{Atıf İçin / Please Cite As:}

Yenen, E. T. (2022). Öğretmenlerin mesleki yeterliklerini etkileyen faktörler. Manas Sosyal Araşttrmalar Dergisi, 11(1), 27-45.

Geliş Tarihi / Received Date: 10.07.2020

Kabul Tarihi / Accepted Date: 19.05.2021

\footnotetext{
${ }^{1}$ Dr. Öğr. Üyesi - Türkiye, Nevşehir Hacı Bektaş Veli Üniversitesi- Eğitim Fakültesi Fakültesi, tamer-yenen@hotmail.com 


\section{Giriş}

Günümüzde hızla gelişen teknolojik ve bilimsel yenilikler toplumları değişimlere açık, aktif bireyler yetiştirmeye zorlamaktadır. Bilgi toplumunun gerekliliklerini bilen ve kendini geliştirebilen bireylerin eğitimi, toplumların kalkınmasında başrol oynamaktadır. Nitelikli bireylerin yetiştirilmesi nitelikli ögrretmenlerle mümkündür. Dolayısıyla günümüz eğitim ihtiyaçlarının karşlanması için, öğretmenlerin birtakım beceri ve yeterliklere sahip olması beklenmektedir.

Eğitim kurumlarının kalitesinin arttırılması ve öğrencilerin istenilen düzeyde başarıya ulaşabilmesi için öğretmen niteliklerinin ve yeterliklerinin yüksek olması gereklidir (Köksal, 2008). Çünkü öğretmenin yeterliği, eğitim ve öğretimin niteliğini doğrudan etkilemektedir (Darling-Hammond, 2006; Karacaoğlu 2008). Yeterlik en genel anlamda; yeterli olma durumu, bir işi yapma gücünü sağlayan özel bilgi, ehliyet olarak tanımlanmaktadır (TDK, 2020). Yeterlik, bireyin bir işi yapabileceğine dair sorumluluk alması ve mesleğini düzgün bir şekilde icra edebilmesi için bireyde var olması beklenen mesleki bilgi, beceri ve tutum gibi özelliklerdir (Yeşilyurt, 2011). Benzer şekilde, öğretmen yeterlikleri de öğretmenlerin "öğretmenlik mesleğini etkili ve verimli bir biçimde yerine getirebilmek için sahip olmaları gereken bilgi, beceri ve tutumlar" olarak açıklanmaktadır (MEB, 2017). Öğretmen yeterlikleri öğretmenlerin mesleki bilgi, beceri ve değer yargıları ile ilgilidir. Öğretmenin mesleki performans1, onun mesleki yeterliği ve öğrenci başarıs1 arasındaki bağ ile açıklanmaktadır (Kulshrestha ve Pandey, 2013).

Öğretmenlerin mesleklerini icra ederken sahip olması gereken bilgi, beceri ve tutumları aynı zamanda ögrencilerine de kazandırması beklenmektedir. Bu bakımdan öğrencilerin ihtiyaç duyduğu bilgi, beceri, tutum ve değerleri geliştirebilmek ve öğretmenlik mesleğini layıkıyla yerine getirebilmek için öğretmenlerin birçok alanda yeterli donanıma sahip olması gerekmektedir (Can, 2019). Günümüz eğitim sorunlarıyla baş edebilmek için öğretmenlerin yeterli bilgi ve beceriye sahip olmaları büyük önem taşımaktadır (Altınkurt ve Ekinci, 2016).

Öğretmen yeterliklerinin ne olması gerektiğine yönelik yapılan ulusal ve uluslararası çalışmalarda alan bilgisi, pedagojik alan (meslek) bilgisi ve genel kültür bilgisi öne çıkan ortak boyutlar olarak kabul görmektedir (Ekiz, 2006; Epstein ve Hundert, 2002; Grossman, 1990; Küçükahmet vd., 1999; Shulman, 1987; Şişman, 2009). Alan bilgisi, bir öğretmenin alanı ile ilgili konu, kavram, ilke ve teorilerin birleştiği bir disiplin bütünü ve bu disiplin içindeki bilgilerin düzenlenmesi olarak ifade edilirken; pedagojik alan bilgisi, ögrretmenlerin özellikle hizmet öncesi eğitimde kendi alan bilgileri ile öğrenme ve öğretim sürecinde kullandıkları strateji, yöntem ve teknik bilgisini ilişkilendirerek konu içeriğini nasıl aktardıkları ve yansıttıkları bilgisini içermektedir (Akkuzu, 2011).

Bir öğretmenin sınıf içi performansında sahip olduğu yeterlikler büyük önem taşımaktadır. Öğretmenler, sürekli güncellenen eğitim-öğretim sürecinin zorluklarıyla yüzleşmek için çok çeşitli yeterliklere ihtiyaç duymaktadır (Yenen ve Kılınç, 2018). Bu nedenle öğretmen yeterliklerine yönelik hem ulusal hem de uluslararası ölçekte yeni düzenlemeler ve güncellemeler yapılmaktadır. Bu doğrultuda Millî Eğitim Bakanlığ Öğretmen Yetiştirme ve Geliştirme Genel Müdürlüğünün önderliğinde 2017 yllında yeni yeterlikler belirlenmiş ve yürürlüğe konmuştur. Güncellenen Öğretmenlik Mesleği Genel Yeterlikleri; "mesleki bilgi", "mesleki beceri”, "tutum ve değerler" olmak üzere 3 ana yeterlik alanı ile bu yeterliklere ilişkin 11 alt yeterlik ve bu yeterliklerin altında yer alan 65 göstergeden oluşmaktadır (MEB, 2017). Mesleki bilgi; alan bilgisi, alan eğitimi bilgisi, mevzuat bilgisini kapsarken, mesleki beceri; eğitim öğretimi planlama, öğrenme ortamları oluşturma, öğretme ve öğrenme sürecini yönetme, ölçme ve değerlendirmeyi, tutum ve değerler ise; millî, manevi ve evrensel değerler, öğrenciye yaklaşım, iletişim ve iş birliği, kişisel ve meslekî gelişim alt yeterliklerini içermektedir (MEB, 2017, s. 8).

Yukarıda belirtilen yeterlik alanlanından, öğretmenlerin birçok farklı alanda mesleki yeterliğe sahip olmaları gerektiği görülmektedir. Bu yeterliklerin öğretmenler tarafindan içselleştirilebilmesi için ögretmenlerin bireysel ve kurumsal olarak meslekî gelişimlerinin süreklilik arz etmesi gerekmektedir. Ancak, bireysel, kurumsal, yasal ve pedagojik pek çok faktör nedeniyle öğretmenlerin meslekî gelişimleri tam olarak sağlanamamakta ve bu konuda farklı sorunlarla karşılaşılmaktadır (Can, 2019). Bununla birlikte eğitimdeki bürokratik yapının aşıı merkeziyetçi olması, öğretmenlerin kendileri ile ilgili alınan kararlara katılamaması, motivasyon eksikliği ve kişisel engeller gibi sorunların öğretmenlerin mesleki gelişimlerinin önündeki engeller olarak sayılabilir (Papadopoulou ve Yirci, 2013; Yirci, 2017). Bu sorunların çözümü için öncelikle ögrretmenlerin meslekî yeterlilerini etkileyen faktörlerin belirlenmesi ve bu doğrultuda hizmet öncesinde öğretmen adaylarına hizmet içinde de öğretmenlere yönelik meslekî gelişim faaliyetlerin düzenlenmesi faydalı olabilir. Çünkü Türkiye'de mesleki gelişim anlayışı genel olarak merkezden taşra 
teşkilatlarına doğru ilerleyen bir yapıdadır ve bireysel sorunlardan ziyade genele odaklanılmaktadır. Bu tarzda düzenlenen mesleki gelişim programları, sürekli tertip edilen ancak mecburiyet duygusuyla yürütülen, zaman alıcı ve gereksiz ihtiyaçları karşılamaya yönelik etkinlikler olarak görülmektedir (Bümen vd., 2012). Bireylerin ihtiyaçlarından ve karşılaştıkları sorunların çözümünden uzak bir şekilde düzenlenen mesleki gelişim programlarından istenilen verimin alınması beklenemez. Değişim sadece bireysel değil aynı zamanda örgütsel bir süreçtir. Bireylerin değişim ihtiyaçlarını örgüt yapısı göz önünde bulundurmalıdır. Bazen bu durumun tersi de olabilmektedir. Kurum destekleyici ve ilerlemeci bir anlayış sergilerken, bireyler motivasyon düşüklüğü yaşayabilmektedirler (Guskey, 2007). Bu bağlamda öğretmenlerin mesleki yeterliklerini etkileyen faktörlerin bir değişim ihtiyacı olarak görülmesi ve değişimi ihtiyaçlarına yönelik mesleki gelişim programlarının düzenlenmesi gerekmektedir.

\section{Öğretmen Yeterliklerini Etkileyen Faktörler}

Öğretmenlerin mesleğin gerektirdiği bilgi ve beceri gibi donanımlarının yanında, öğretmen niteliğini etkileyen bir diğer faktör de onların görev ve sorumluluklarını yerine getirebileceklerine olan inançlarıdır (Çapa-Aydın, Uzuntiryaki, Temli ve Tarkın, 2013). Bandura (1997) bir işte başarılı olabilmek için sahip olunması gereken yeteneklerin yanında, bireyin başaracağına olan inancının da önemli olduğunu vurgulamıştır. Bir başka deyişle, başarılı olmada bireyin öz yeterlik inancı da etkilidir. Öğretmenlerin sadece alan yeterliklerine sahip olması onların sınıf içi performanslarını nitelikli bir şekilde sergilemeleri için yeterli bir faktör değildir, aynı zamanda bu niteliklerini öğretim sürecine yansıtabilmeleri için öz yeterliklerinin de yüksek olması gerekir (Şahin, 2010).

Bandura, öz yeterliği bireyin belirli bir performans ya da davranışı sergilemek için ortaya koyduğu etkinlikler yoluyla başarllı olabilme kapasitesine olan inancı olarak tanımlamaktadır (Bandura, 1997, s. 15). Bandura (1977) öz yeterlik inançlarını etkileyen faktörleri bireylerin mesleki tecrübelerine, kendi duygularına ve başkalarının bireylerin sergiledikleri ya da sergileyecekleri performanslarına ilişkin yorumlarına dayandırmakta ve öz yeterliğin başlıca dört temel kaynağı olduğunu ifade etmektedir. Bunlar; mesleki deneyimler, dolaylı yaşantılar, sözel ikna ve duygu durumlarıdır.

Mesleki deneyimler bireyin işi ile ilgili başarll ya da başarısızlıkla sonuçlanan tecrübelerdir (Senemoğlu, 2013). Bandura (1977) öğretmenlerin mesleki yeterliliğe sahip olmasındaki en önemli faktörün doğrudan yaşanılan mesleki deneyimler olduğunu belirtmektedir. Çünkü birey geçmişteki mesleki tecrübelerini değerlendirerek, benzer eylemleri gerçekleştirme kapasiteleri konusunda bir yeterlik inanc1 geliştirir. Bireyin başarıyla sonuçlanan eylemleri öz yeterlik inancını arttırırken, yaşadığı başarısızlıklar öz yeterlik inancını olumsuz etkilemektedir (Pajares, 2002). Bu bağlamda öğretmenlerin genel ve kişisel öz yeterlik inançlarının geliştiği en önemli dönemlerden biri olan hizmet öncesi dönemde aldıkları dersler ve yaptıkları uygulamaların sonucunda edindikleri tecrübeler bireylerin öz yeterliklerine ilisskin inançlarını geliştirmektedir (Kızkapan ve Kırmızı̈ül, 2021). Gürbüz, Erdem ve Gülburnu (2013) çalışmalarında, ögretmenlerin mesleki deneyimlerinin, öğretmen yeterliğini etkileyen bir faktör olduğunu belirtmişler ve çalışmalarındaki katıllımcıların büyük çoğunluğunun mesleki deneyimin öğretmen yeterliğini olumlu etkilediğini ve öğrenci başarısını arttırdığını dile getirdiklerini ifade etmişlerdir. Dolaylı yaşantılar bireyin kendi mesleği ile ilgili alanlardaki diğer bireylerin gözlemlenmesine dayanmaktadır. Birey gözlemlediği ya da model aldığı kişinin ortaya koyduğu bir ürünü veya sergilediği eylemleri gözlemleyerek kendi yeterliği ile ilgili çıkarımlarda bulunabilmektedir (Gültekin, 2011, s. 116). Sözel ikna, bireyin başkalarından aldığı geri bildirimler ve teşvikler ile ilgilidir (Thompson, 2016). Bireylerin bir konu hakkında aldıkları görüşler, motive edici konuşmalar, olumlu ya da olumsuz eleştiriler o konu hakkındaki şüpheleri ortadan kaldırmada etkili olabilmektedir. Bu bağlamda, görüşü alınan kişinin güvenilirliği, uzmanlı̆̆1 ve saygınlığ1 önemlidir. Başka bir ifadeyle, bir konu alanında öz yeterlik inancı yüksek kişilerin benzer konularda çevresindeki bireylerin öz yeterlik algılarını değiştirebilmektedir (Bolat, 2011). Duygu durumları ise bireyin farklı durumlara gösterdiği tepkileri ve bu durumlara yönelik algilarını ifade etmektedir (Heaton, 2013). Bireyin ruh hali, stres, korku ve gerginlikleri onun öz yeterlik algilarını etkileyebilmektedir (Lee, 2009). Diğer bir deyişle, bireyin bir işi yaparken taşıdığı olumlu duygular öz yeterliğini olumlu etkilerken, içinde bulunduğu olumsuz ruh hali ya da yapacağ işe karşı duyduğu kaygılar öz yeterliğini olumsuz etkilemektedir.

Öğretmen yeterliklerinin hangi faktörlerden etkilendiğinin ve gelişimine ne tür faktörlerin katkıda bulunduğunun tespit edilmesi büyük önem taşımaktadır, çünkü bu faktörler öğretmenlerin yetenekleri ve yeterlilikleri hakkında kendi teorik ve pratik yargılarını anlamak için gereklidir (Tschannen-Moran ve Woolfolk Hoy, 2007). Aynı zamanda öğretmen yeterliğini etkileyen faktörlerin neler olduğu hakkında bilgi sahibi olmak, ögretmenlerin yeterlik yargılarını güçlendirmek açısından da önemlidir. Bandura’nın öne 
sürdüğü öz yeterlik ve başarı arasındaki ilişki göz önünde bulundurulduğunda, yeterlik alg1sı yüksek olan öğretmenlerin daha etkili bir öğretim gerçekleştireceği söylenebilir (Çapa-Aydın ve diğer., 2013). Dolayısıyla, öğretmen yeterliğini etkileyen ve geliștiren kaynakların bilinmesi ile öğretimin daha etkili olması sağlanabilir.

İlgili literatürde öğretmenlerin ve öğretmen adaylarının öz yeterlik inançlarına yönelik yapılan çalışmalarla kıyaslandığında, bu inançların kaynakları ile ilgili çalışmalar sınırlı sayıda kalmaktadır. (ÇapaAydın vd., 2013; Heaton, 2013; Henson, 2002; Mulholland ve Wallace, 2001; Phan ve Locke, 2015; Tschannen-Moran, Woolfolk Hoy ve Hoy, 1998; Usher ve Pajares, 2008). Yine de, literatürde diğer öğretim konu alanlarında öğretmen yeterlik inançlarının oluşumunu etkileyebilecek faktörleri saptamak için dikkate değer girişimler olmuştur. Örneğin Akkuzu (2011) kimya öğretmeni adaylarında bulunması gereken yeterlilikler ve bu yeterlilikleri etkileyen faktörleri inceleyen yapısal eşitlik modeli çalışmasında, öğretmen adaylarının kimya öğretimi öz yeterlik inançları, öğretmenlik mesleğine yönelik tutumları, meslek deneyimleri ve alan bilgileriyle yüksek derecede ilişkili olduğunu tespit etmiştir. Sevimel ve Subaşı (2018) İngilizce öğretmen adaylarının yeterliklerinin dört temel faktörden etkilendiğini ve bunları önem sırasına göre üniversite eğitimi, öğretmenlik uygulamaları, dil yeterlikleri ve duygu durumları olarak belirtmişlerdir. Yeung ve Watkins (2000) de benzer şekilde öğretmenlerin yeterlik inançlarının en çok öğretmenlik uygulamalarından etkilendiğini, bunun yanı sıra eğitim çalışmalarının, danışman öğretmenlerin, ögrencilerin, ders ve ders planlarının da yeterlik inançları üzerinde etkili olduğunu saptamışlardır. Paulou (2007) da çalışmasında, Bandura'nın temel yeterlik inancı kaynaklarına ek olarak, kişilik özelliklerinin, motivasyonun, bireysel yeteneklerin ve üniversite eğitiminin öğretmen yeterliklerini etkileyen faktörler olarak ifade etmektedir.

Öğretmenlerin meslekî yeterlik gelişimlerinin sağlanabilmesi için, öğretmen yeterliklerini etkileyen faktörlerin belirlenmesi ve bu engellerin belirlenerek öğretmen yeterliklerinin arttırllmasına yönelik

önerilerin geliştirilmesi büyük önem taşımaktadır. Literatür incelendiğinde, başta Bandura’nın öz yeterliği etkileyen dört kaynak modeli olmak üzere, öğretmenlerin farklı nedenlere bağlı olarak meslekî yeterliklerinin etkilendiği görülmektedir. Ancak, Bandura’nın ortaya koymuş olduğu öz yeterliği etkileyen bu dört kaynak modeli, farklı branşlardan öğretmenlerin katılımlarıyla genişletilebilir. İlgili alanda yapılan çalışmaların genellikle nicel çalışmalar olduğu, nitel araştırmaların ise sınırlı sayıda olduğu göz önünde bulundurulduğunda, öğretmen görüşlerine bağlı olarak nitel araştırma yöntemleri ile öğretmenlerin meslekî yeterliklerini etkileyen faktörlerin belirlenmesi ve bu bağlamda çözüm önerilerinin ortaya koyulmas1 araştırmayı önemli kılmaktadır.

$\mathrm{Bu}$ araştırmanın amacı, öğretmenlerin meslekî yeterliklerini etkileyen faktörleri belirlemek ve ögretmenlerin meslekî yeterliklerini arttırabilmeleri için öneriler sunabilmektir. Bu doğrultuda çalışmada aşağıldaki sorulara yanıt aranmıstır:

1. Öğretmenlerin genel olarak mesleki yeterliklerini etkileyen faktörlere ilişkin görüssleri nelerdir?

2. Öğretmenlerin hizmet öncesi aldıkları eğitimin mesleki yeterliklerine olan etkisine ilişkin görüşleri nelerdir?

3. Öğretmenlerin mesleki deneyimlerinin mesleki yeterliklerine olan etkisine ilişkin görüşleri nelerdir?

4. Öğretmenlerin okul ortamı ve bu ortamdaki sosyal ilişkilerinin mesleki yeterliklerine olan etkisine ilişkin görüşleri nelerdir?

5. Öğretmenlerin duyuşsal durumlarının mesleki yeterliklerine olan etkisine ilişkin görüşleri nelerdir?

6. Öğretmenlerin mesleki gelişimlerinin mesleki yeterliklerine olan etkisine ilişkin görüşleri nelerdir?

7. Öğretmenlerin mesleki anlamda kendilerini yetersiz buldukları alanlara yönelik görüşleri nelerdir?

8. Öğretmenlerin mesleki yeterliliklerini geliştirebilmelerine yönelik önerileri nelerdir?

\section{Yöntem}

$\mathrm{Bu}$ araştırma nitel araştırma deseni kapsamında yürütülmüştür. Nitel araştırmalar genellikle bir konu hakkında derinlemesine ve kapsamlı bilgi edinmek amacıyla kullanılmaktadır (Patton, 2014).

\section{Çalışma Grubu}

Araştırmanın çalışma grubunu 2019-2020 Eğitim Öğretim yllında Aksaray, Kayseri ve Nevşehir illerinde farklı branşlarda görev yapan gönüllü 20 öğretmen oluşturmaktadır. Katılımcıların belirlenmesinde kolay ulaşılabilir durum örneklemesi kullanılmıştır. Kolay ulaşılabilir durum örneklemesi nitel 
araştırmalarda sıklıkla kullanılmaktadır ve araştırmacıya özellikle süre bakımından avantajlar sağlamaktadır (Yıldırım ve Şimşek, 2013). Katılımcılara ilişkin demografik bilgiler Tablo 1'de sunulmuştur.

Tablo 1. Katılimcilara Ait Demografik Bilgiler

\begin{tabular}{|c|c|c|}
\hline \multicolumn{2}{|c|}{ Demografik Bilgiler } & $f$ \\
\hline \multirow{2}{*}{ Cinsiyet } & Kadin & 9 \\
\hline & Erkek & 11 \\
\hline \multirow{7}{*}{ Branş } & Sinif & 5 \\
\hline & İngilizce & 4 \\
\hline & Türkçe & 4 \\
\hline & Matematik & 3 \\
\hline & Sosyal Bilgiler & 2 \\
\hline & Fen Bilgisi & 1 \\
\hline & Din Kültürü ve Ahlak Bilgisi & 1 \\
\hline Toplam & & 20 \\
\hline
\end{tabular}

\section{Veri Toplama Aracı}

Çalışmada veri toplama aracı olarak yarı yapılandırılmış görüşme formu kullanılmıştır. Araştırmacı tarafindan geliştirilen form öğretmenlerin mesleki yeterliklerini etkileyen faktörlere ilişkin düşüncelerini açığa çıkaran açık uçlu sekiz sorudan oluşmuştur. Görüşme formu oluşturulurken alanyazın taranmış ve uzman görüşleri alınmıştır. İki Eğitim Programları ve Öğretim alanı, biri de Eğitim Yönetimi alanı uzmanı olmak üzere toplamda üç akademisyenin görüşleri doğrultusunda gerekli düzeltmeler yapılarak görüşme formunun taslağı hazırlanmışır. Taslak haline getirilen görüşme formu uygulamaya geçilmeden önce iki sınıf öğretmenine ön uygulama yapılmıştır. Ön uygulama sonucunda görüşme formunun sıkıntısız bir şekilde uygulandığına kanaat getirilerek görüşme forumunun son şekli verilmiştir.

\section{Verilerin Toplamas1}

Araştırmanın verileri 2019-2020 Eğitim Öğretim yllında Aksaray, Kayseri ve Nevşehir illerinde farklı branşlarda görev yapan 20 öğretmenden toplanmıştır. Görüşmeler yüz yüze yapılmıştır. Her bir görüşme ortalama 20-25 dakika arası sürmüştür. Görüşmelerde ses kaydı gönüllük esasına göre yapılmıştır. 8 katılımcı ses kaydına izin verirken, 12 katılımcının görüşleri not edilerek alınmıştır.

\section{Verilerin Analizi}

Araştırmanın verileri içerik analizi yöntemi kullanılarak analiz edilmiştir. Elde edilen verilerin çözümlenmesinde bilgisayar destekli nitel veri analizi programı kullanılmıştır. Görüşme verilerinden çıkarılan kavramlar benzerliklerine ve farklılıklarına göre kod ve temalara ayrılmıştır. Belirlenen kod ve temalar iki uzamanın görüşüne sunularak kapsam geçerliği sağlanmıştır. Daha sonra veriler nihai temalara ve kodlara ayrılıp şekiller halinde frekansları belirtilerek sunulmuştur. Ayrıca, araştırma bulgularının içgüvenirliğini ve inanırllğını artırmak amacıyla öğretmen görüşlerinden aslına uygun olarak sıkça alıntılar yapılmıştır. Katılımcıların görüşleri öğretmenleri temsilen Öğretmen 1(Ö1), Öğretmen 2 (Ö2),....şeklinde kodlanmıştır.

Araştırmada ayrıca görüşmelerden elde edilen sonuçların iç ve diş güvenirliğini sağlamak amacıyla, bulguların gerçekliğine ilişkin kanıtların ortaya konması, benzer süreçlerin birbiriyle uyumlu olması ve sonuçların benzer ortamlarda karşılaştırılabilmesi için, objektif bir yaklaşımla toplanan veriler ve sonuçları yine objektif olarak okuyucuya sunulmaya çalışılmışıtır.

\section{Bulgular}

Araştırmada katılımcılarla yapılan görüşmelerden elde edilen veriler analiz edilmiş, yöneltilen sorulara bağlı olarak cevaplar analiz edilmiş, ulaşılan tema ve kodlar modeller aracıllı̆̆yla görselleştirilmiş ve değerlendirilmiştir. 


\section{Öğretmenlerin Genel Olarak Mesleki Yeterliliği Etkileyen Faktörlere İlişkin Görüşleri}

Öğretmenlerin mesleki yeterliliği etkileyen faktörlere ilişkin görüşlerini almak üzere "Sizce bir ögretmenin mesleki yeterliliklerini etkileyen faktörler nelerdir?” sorusu yöneltilmiştir. Öğretmenlerin verdikleri cevaplar doğrultusunda, oluşturulan temaya ait kodlar ve frekanslarını gösteren model aşağıda yer almaktadır.

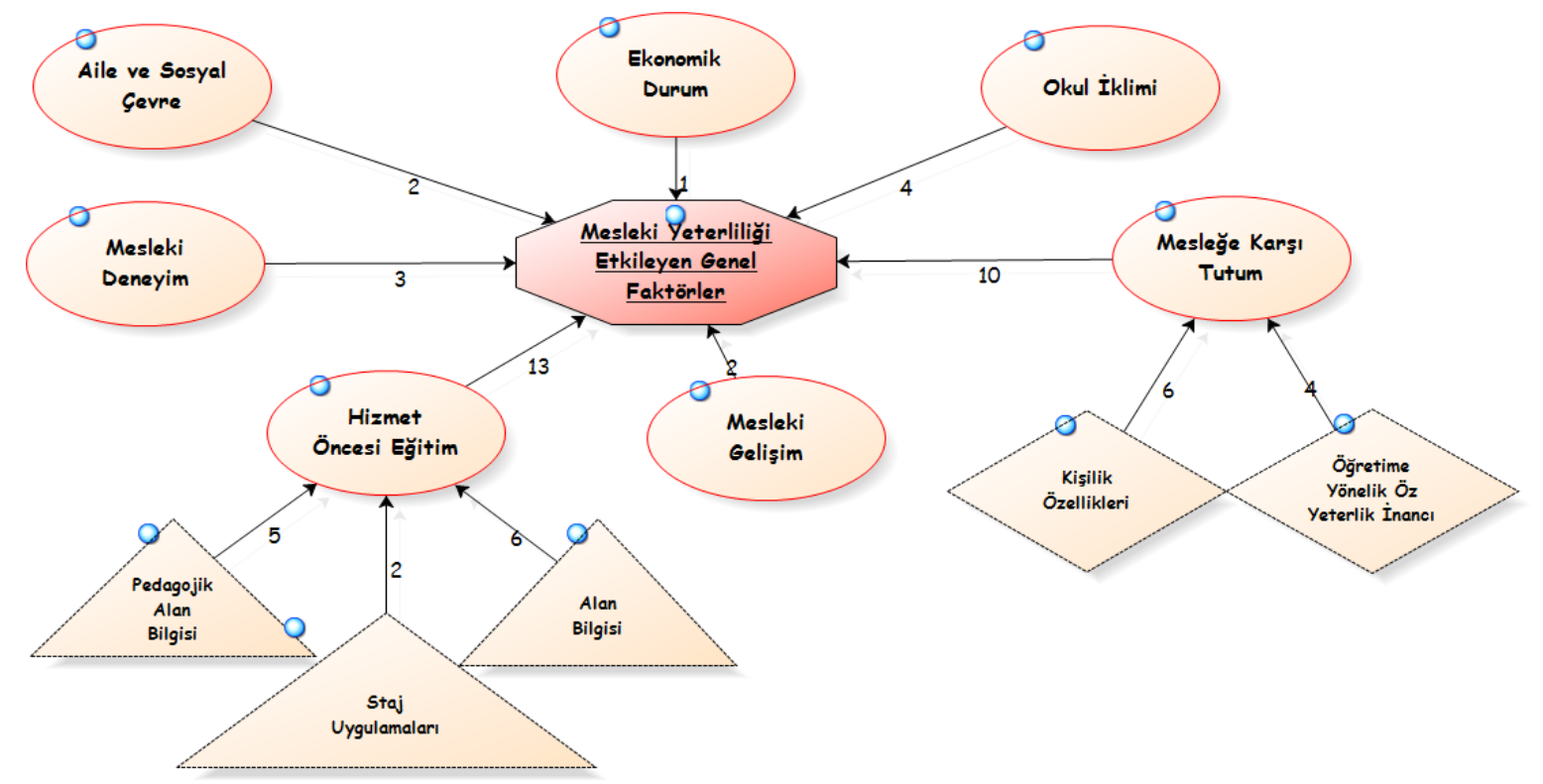

Şekil 1. Öğretmenlerin Mesleki Yeterliliğini Etkileyen Faktörler

Şekil 1'de görüldüğü üzere öğretmenlerin mesleki yeterliliği etkileyen faktörlere ilişkin verdikleri cevaplar farklılık göstermektedir. Katılımcı görüşleri incelendiğinde, hizmet öncesi eğitim başlı̆̆ altında; alan bilgisi, pedagojik alan bilgisi, staj uygulamaları, mesleğe karşı tutum başlığı altında; kişilik özellikleri, öğretime yönelik öz yeterlik inancının mesleki yeterliliği etkilediği görülmektedir. Katıllımcı görüşlerine göre mesleki yeterliği etkileyen diğer faktörler olarak okul iklimi, mesleki deneyim, aile ve sosyal çevre, mesleki gelişim ve ekonomik durum kodları ortaya çıkmaktadır. Araştırmaya katılan öğretmenlerin görüşlerinden bazıları aşağıda sunulmuştur:

\section{Hizmet öncesi eğitim}

\section{Mesleğe karş1} tutum

Okul iklimi

Mesleki

deneyim

Mesleki gelişim

Aile ve sosyal çevre; Ekonomik durum

Bu bulgulara göre öğretmenlerin mesleki yeterliliğini etkileyen genel faktörlerin en çok hizmet öncesi eğitim başlı̆̆1 altında alan bilgisi, pedagojik alan bilgisi, staj uygulamaları kodlarında toplandığ1; bunu mesleğe karşı tutum başlı̆̆1 altında kişilik özellikleri ve öğretime yönelik öz yeterlik inancının takip ettiği söylenebilir.
Ö5, "Hizmet öncesi alnan eğitim çok önemlidir. Cünkü kendi alan ile ilgili ve ögretmenlik ile ilgili bilgilerin yeterli donanml verilmesi gerekir ki ögretmende bizmet içinde iken o bilgiler ile kendini yeterli hissetsin. Yeterli hissetsin kendini yenilemesin anlamında değil sürekli yine kendini geliștirsin yeniliklere açı. olsun. Hizmet öncesi alonan stajyerliğinde ögretmenin hiæ̧met içi sürecine olumlu yönde etki eder. Hatta hizmet öncesi alınan eğitimlerde stajyerlik ynlin daha fazla vermeleri gerektiğini düsünnüyorum."

Ö1, "Bir ögretmenin mesleki yeterliliğini etkileyen faktörlerden birisi ögretmenlik mesleğini bilerek ve isteyerek tercih etmesi, işini severek yapıyor olmasider. Insan sevdiği, yapmaktan mutlu olduğu isste kendisini daha rahat ve buzurlu bissettiği için verimi fazla olacaktır. İsine duyduğu aşkla kendisini sürekli yenilemek isteyecek, kendini gelistirmenin yollarm arayacaktor.

Ö8, "Okul atmosferi önemli bir faktör bence. İdarecilerin ve zümrelerin anlayzssszsa ve ortak paydalarla bulusamiyorsan kendini tam anlamylla göstermezsin."

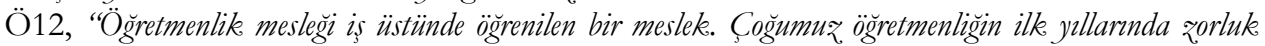
cekmişizdir. Zaman gectikece hatalarndan ders alp daha iyi oluyorsun.."

Ö18 "Öğretmen durağan olmamal, sürekli yenilikleri takip ederek yeterliklerimizi gelisstirebileceğimizi düsünüyorum"

Ö7 "...sadece akademik anlamdaki durumlarla yeterlikler açılanamayabilir. Öğretmen de tüm insanlar gibi sosyal bir varlk. Ailesindeki, gevresindeki durumlardan olumsuz etkilenebilir. Bu duruma ekonomik. etmenlerde dabi edilebilir..." 


\section{Hizmet Öncesi Eğitimin Mesleki Yeterliliğe Etkisi}

Öğretmenlerin hizmet öncesi eğitimin mesleki yeterliklerine olan etkisine ilişkin görüşlerini almak üzere "Hizmet öncesi (Üniversite eğitimi) aldığınız eğitimin (Alan bilgisi ve pedagojik bilgi) mesleki yeterliliklerinize olan etkisini açılar mısınız?" sorusu yöneltilmiştir. Öğretmenlerin verdikleri cevaplar doğrultusunda, bu soruya ilişskin oluşturulan temaya ait kodlar ve frekanslarını gösteren model aşağıda sunulmuştur.

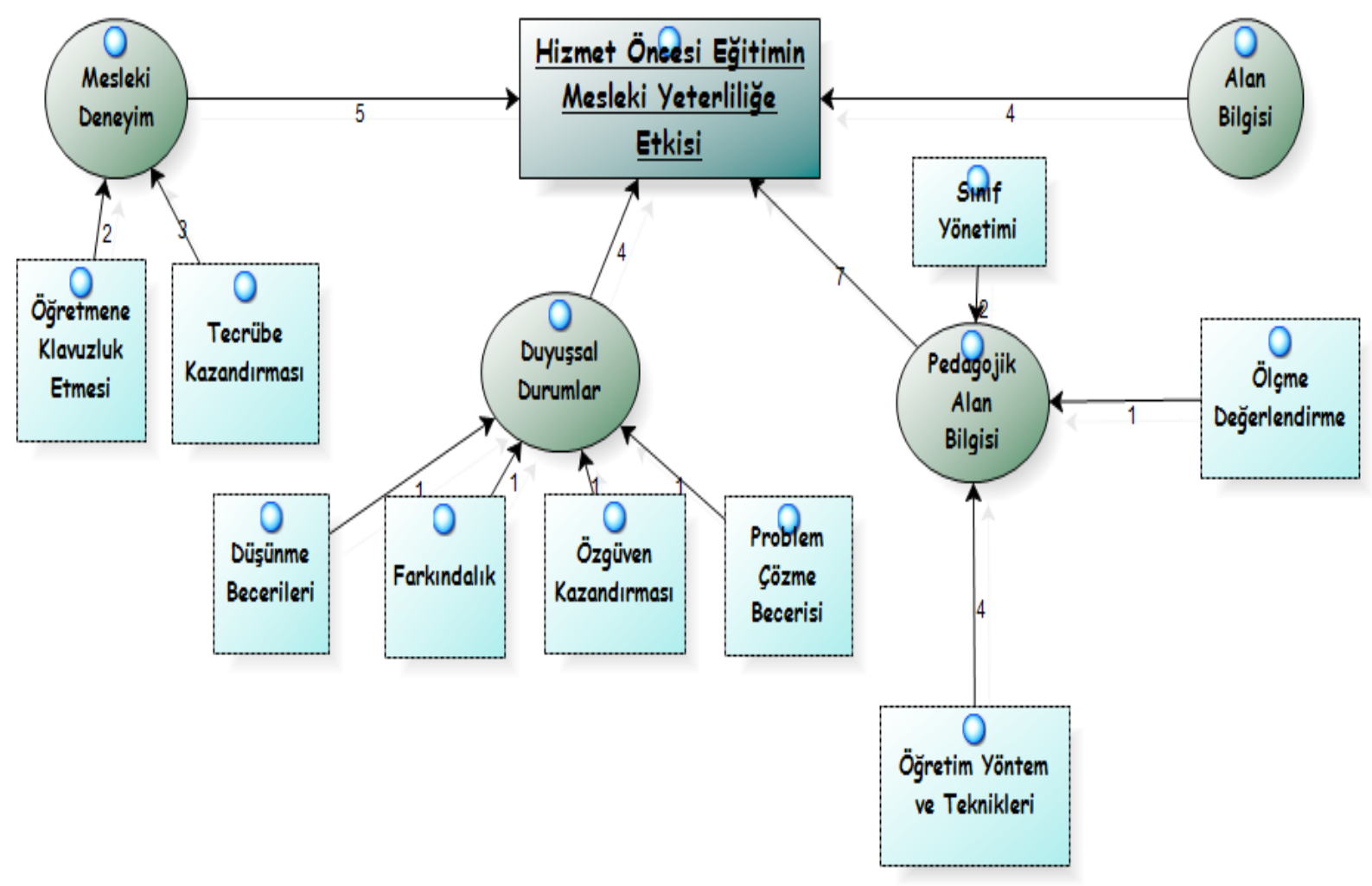

Şekil 2. Hižmet Öncesi Eğitimin Mesleki Yeterlilïge Etkisi

Şekil 2 incelendiğinde öğretmenlerin hizmet öncesi eğitimin mesleki yeterliliğe etkisine ilişkin verdikleri cevapların çeşitlilik gösterdiği anlaşılmaktadır. Öğretmenlerin bu soruya verdikleri cevaplar analiz edildiğinde; pedagojik alan bilgisi başlı̆̆1 altında öğretim yöntem ve teknikleri, sınıf yönetimi, ölçme değerlendirme, mesleki deneyim başlı̆ı altında tecrübe kazandırması, öğretmene kılavuzluk etmesi, duyuşsal durumlar başı̆̆ı alında düşünme becerileri, farkındalık, özgüven kazandırması, problem çözme becerisi ve alan bilgisi faktörlerinin mesleki yeterliliği etkilediğini ifade ettikleri görülmüştür. Katıllmc1 görüşlerinden bazıları aşağıda sunulmuştur:

\begin{tabular}{|c|c|}
\hline Pedagojik alan bilgisi & $\begin{array}{l}\text { Ö2, "Üniversitede almıs olduğum ölcme değerlendirme, özel eğitim teknikleri, rehberlik gibi } \\
\text { pedagojik bilgiler ögretmenlik hayatımda bana kilavuzluk etmistir." }\end{array}$ \\
\hline Mesleki deneyim & $\begin{array}{l}\text { Ö17, "Ögretmenlik uygulamalar bu süreçte çok önemli. Mesleğin ilk ynllarnda özellikle okul } \\
\text { uygulamalarndaki deneyimlerinden ve danş̧man ögretmenin tavsiyelerinden faydalanyorsun" }\end{array}$ \\
\hline Alan bilgisi & $\begin{array}{l}\text { Ö5, "Eğer ögretmen yeterli alan bilgisine sahip olursa aldiğ eğitimde hem kendine, işine olan } \\
\text { özgüveni sağlamıs olur hem de özgüven sabibi olursa ișine de olumlu yansır." }\end{array}$ \\
\hline Duyuşsal durumlar & $\begin{array}{l}\text { Ö20, "Bir kere sana öz güven kazandiryor. Hiçbir şey ögrenmeden nasıl kendini yeterli } \\
\text { hissedebilirsin ki?..." }\end{array}$ \\
\hline
\end{tabular}

Bu temaya ilişkin yapılan analizlerde, hizmet öncesi eğitimde sırasıyla pedagojik alan bilgisinin, mesleki deneyimin, alan bilgisinin ve duyuşsal durumların öğretmenlerin mesleki yeterliklerine etki ettiği, öğretmenler tarafindan en çok ifade edilen kodun ise öğretim yöntem ve teknikleri olduğu tespit edilmiştir.

\section{Mesleki Deneyimin Mesleki Yeterliliğe Etkisi}

Öğretmenlerin mesleki deneyimin mesleki yeterliliğe etkisine ilişkin görüşlerini almak üzere "Mesleki deneyimlerinizin mesleki yeterliliğinize etkileri hakkındaki düşünceleriniz nelerdir?”" sorusu yöneltilmiştir. 
Öğretmenlerin verdikleri cevaplar doğrultusunda oluşturulan temaya ait alt temalar ve frekanslarını gösteren model Şekil 3’te sunulmuştur.

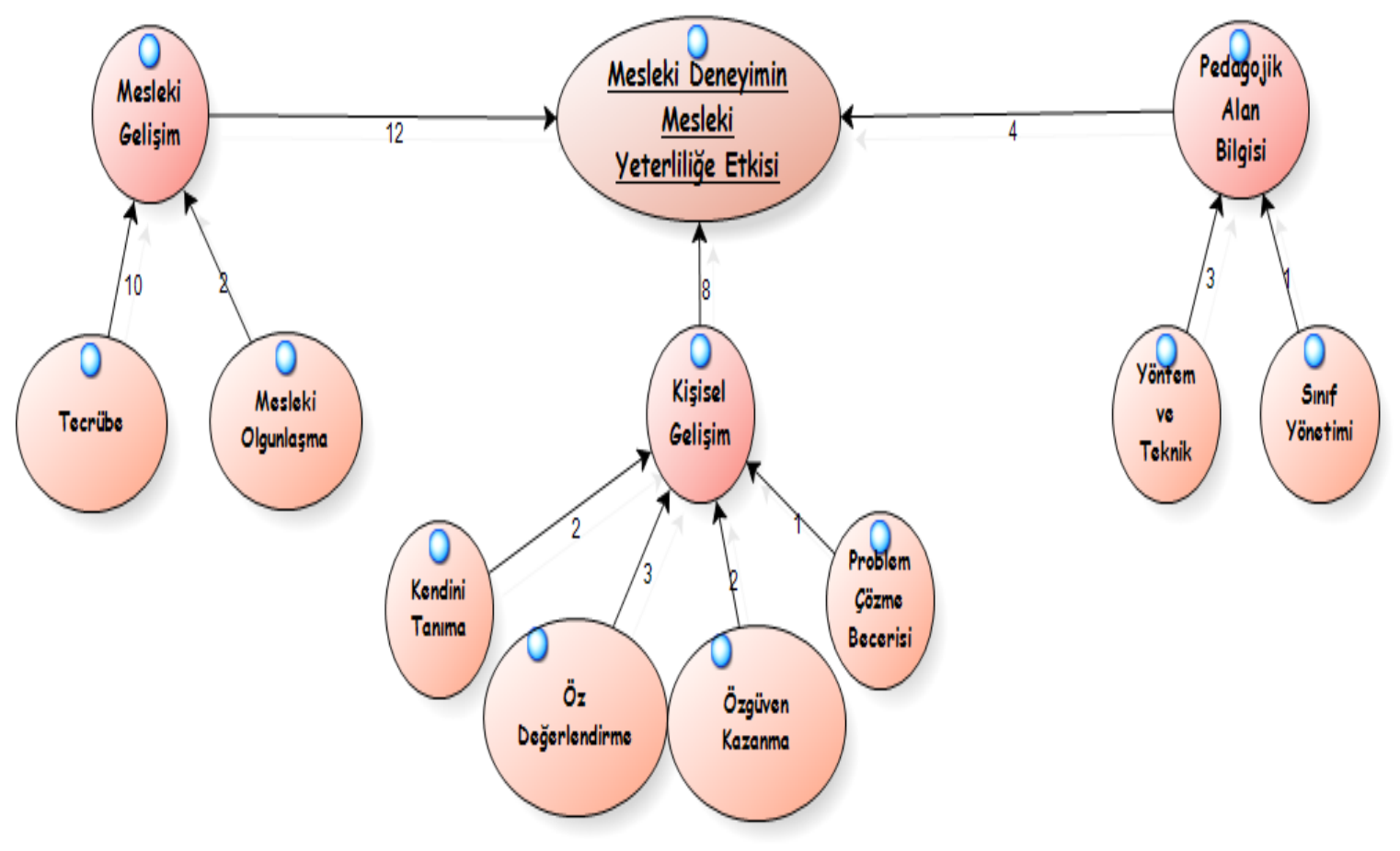

Şekil 3. Mesleki Deneyimin Mesleki Yeterliliğe Etkisi

Şekil 3’de de görüldüğü üzere öğretmenlerin mesleki deneyimin mesleki yeterliliğe etkisine ilişkin verdikleri cevaplar arasında en çok görüş alan alt tema mesleki gelişim olmuştur ( $\mathrm{f}=12$ ). Katılımcılar mesleki gelişim başlı̆̆ altında tecrübenin ve mesleki olgunlaşmanın önemine değinmişlerdir. Bunun yanı sıra, ögretmenler mesleki deneyimde kişisel gelişimin ve pedagojik alan bilgisinin mesleki yeterliği etkilediğini ifade etmişlerdir. Katılımcı öğretmenlerin bu soruya verdikleri cevaplardan bazıları aşağıda sunulmuştur:

\begin{tabular}{|c|c|}
\hline Mesleki gelişim & 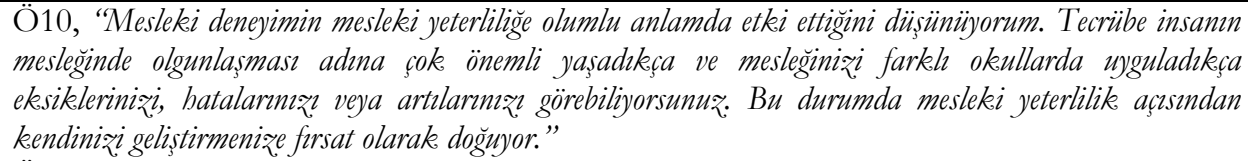 \\
\hline Kişisel Gelişim & $\begin{array}{l}\text { Ö15, "Her ögrenci farkh bir karakter. Dolayısıla müfredata bağh konular anlatılirken ögrencinin } \\
\text { gereksinimine göre anlatım teknikleri daha iyi oturuyor. Problem çözme becerin gelisisyor. Deneyim } \\
\text { mutlaka meslekte insan gelistiren bir etken." }\end{array}$ \\
\hline $\begin{array}{l}\text { Pedagojik alan } \\
\text { bilgisi }\end{array}$ & $\begin{array}{l}\text { Ö19, "Mesleki deneyimin önemli olduğunu düsünüyorum, gerek sinf yönetimi gerekse konu anlatımı, } \\
\text { uygulanacak yöntem ve tekniğin seçilmesi aşamasında çok etki ediyor. Mesleki yullar geçtikçe ögretmen } \\
\text { kendini gelistirmeye devam ettikeşe, hangi konuyu nerede ve nasıl vereceğini daha iyi biliyor." }\end{array}$ \\
\hline
\end{tabular}

Bu bulgulara göre mesleki deneyimde öğretmenlerin kendilerini hem mesleki hem de kişisel anlamda geliştirmelerinin mesleki yeterliklerini olumlu yönde etkileyebileceği; bununla birlikte mesleki deneyimin öğretim yöntem ve tekniklerini etkili kullanabilme ve sınıf yönetimini sağlama açısından mesleki yeterliğe katkısı olduğu söylenebilir.

\section{Okul Ortamı ve Sosyal İlişkilerin Mesleki Yeterliliğe Etkisi}

Öğretmenlerin okul ortamı ve sosyal ilişkilerin mesleki yeterliliğe etkisine ilişkin görüşlerini almak üzere "Okul ortamı ve bu ortamdaki paydaşlarla (öğretmen, öğrenci, yönetici, veli vb.) olan sosyal ilişkilerin öğretmen yeterliliklerine etkisi hakkında ne düşünüyorsunuz? " sorusu yöneltilmiştir. Öğretmenlerin verdikleri cevaplar doğrultusunda, bu soruya ilişkin oluşturulan temaya ait kodlar ve frekanslarını gösteren model aşağıda yer almaktadır. 


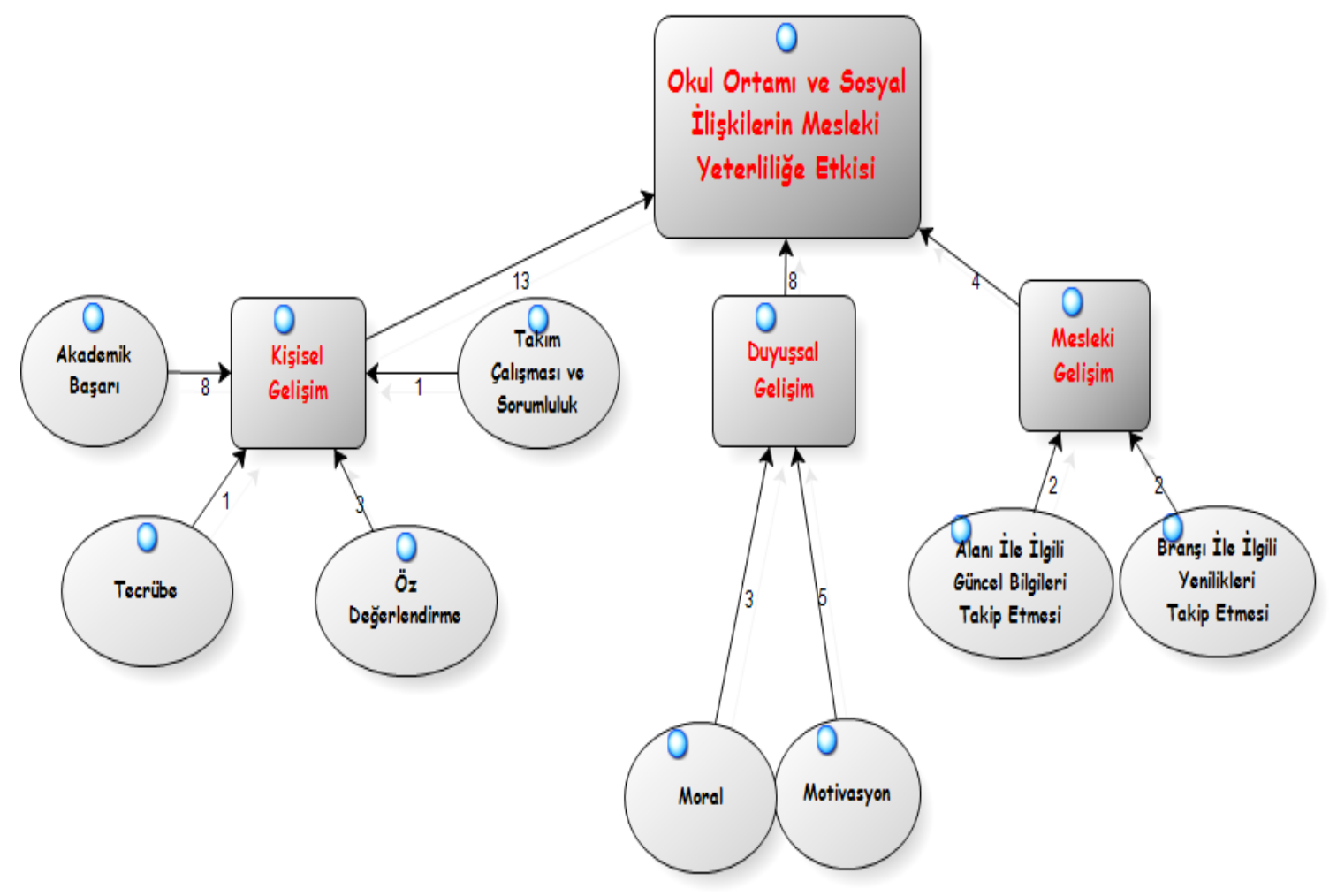

Şekil 4. Okul Ortamı ve Sosyal İlişkilerin Mesleki Yeterliliğe Etkisi

Katılımcıların görüşleri incelendiğinde, okul ortamı ve sosyal ilişkilerin en çok akademik başarıya $(\mathrm{f}=8)$ ve motivasyon'a ( $\mathrm{f}=5$ ) etkisi olduğu görülmektedir. Bunların dışında öz değerlendirme, moral, alanı ve branşı ile ilgili yenilikleri takip etmesi, takım çalışması ve sorumluluk ve tecrübe kodlarına ulaşılmıştır. Araştırmaya katılan öğretmenlerin bu soruya verdikleri cevaplardan bazıları şöyledir:

\begin{tabular}{|c|c|}
\hline $\begin{array}{l}\text { Kişisel } \\
\text { gelişim }\end{array}$ & 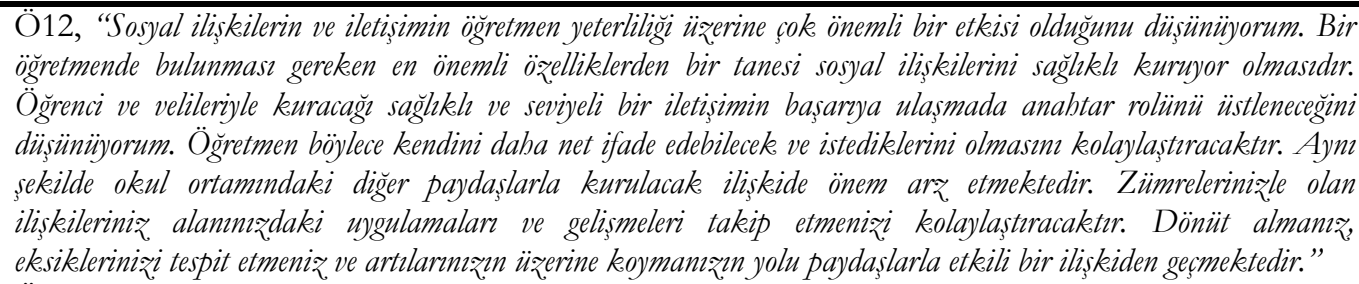 \\
\hline $\begin{array}{l}\text { Duyuşsal } \\
\text { gelişim }\end{array}$ & 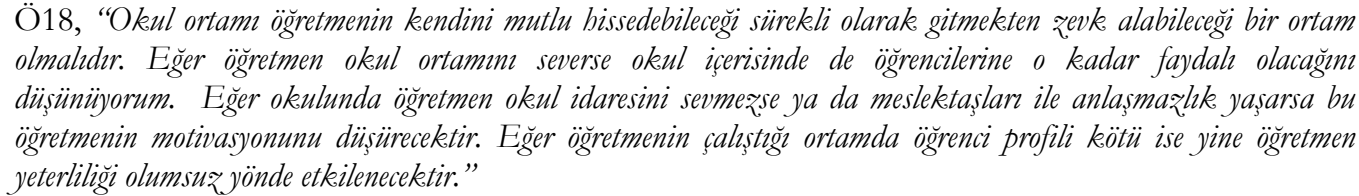 \\
\hline $\begin{array}{l}\text { Mesleki } \\
\text { gelişim }\end{array}$ & 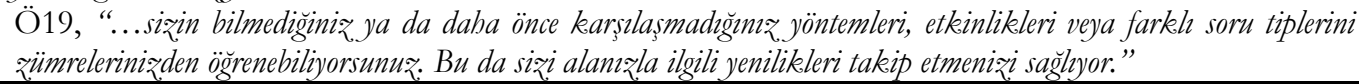 \\
\hline
\end{tabular}

$\mathrm{Bu}$ bulgulara göre okul ortamı ve sosyal ilişkilerin mesleki yeterliliğe kişisel gelişim başlı̆̆ altında akademik başarı sağlama, öz değerlendirme, tecrübe kazandırma, takım çalışması ve sorumluluk; duyuşsal gelişim başlığı alında motivasyon ve moral kazandırma ile mesleki gelişim başlı̆̆ı alında alanı ve branşı ile ilgili güncel bilgileri ve yenilikleri takip etmesi gibi faktörlerin mesleki yeterliliğe olumlu yönde katk1 sağladığı söylenebilir.

\section{Duyuşsal Durumların Mesleki Yeterliliğe Etkisi}

Öğretmenlerin duyuşsal durumların mesleki yeterliliğe etkisine ilişkin görüşlerini almak üzere "Kişilik özellikleri, motivasyon ve mesleğe karşı tutum gibi duyuşsal durumların mesleki yeterlilikleriniz üzerindeki etkileri hakkında ne düşünüyorsunuz?” sorusu yöneltilmiştir. Öğretmenlerin verdikleri cevaplar 
doğrultusunda, bu soruya ilişkin oluşturulan temaya ait kodlar ve frekanslarını gösteren model aşağıda yer almaktadir.

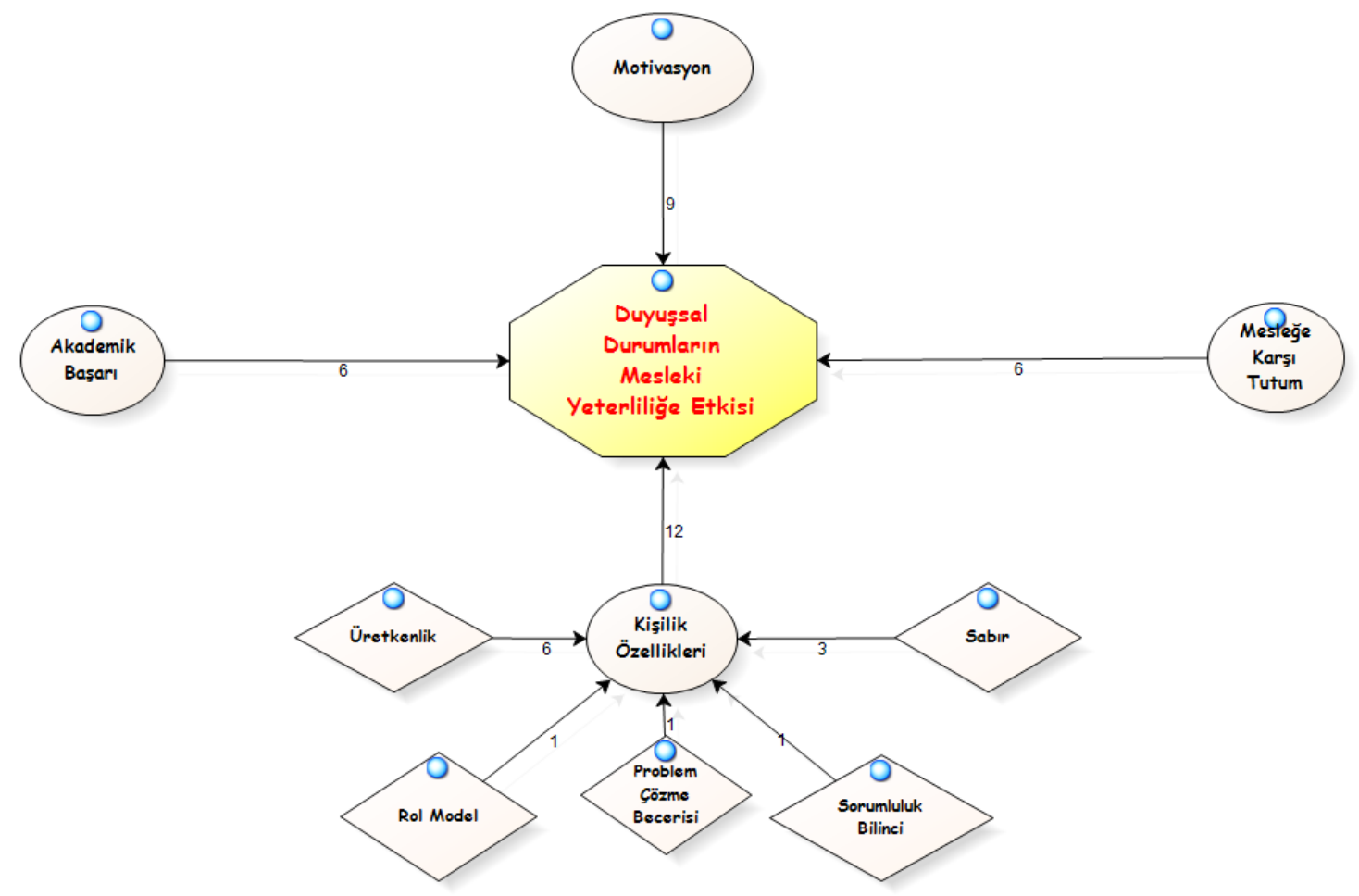

Şekil 5. Duyussal Durumlarn Mesleki Yeterliliğe Etkisi

Öğretmenlerin duyuşsal durumların mesleki yeterliliğe etkisine ilişkin verdikleri cevaplar incelendiğinde, kişilik özellikleri başlı̆̆1 altında üretkenlik, sabır, rol model, problem çözme becerisi, sorumluluk bilinci faktörlerinin ön plana çıtı̆̆1 görülmektedir. Ayrıca, öğretmenlerin verdikleri cevaplardan duyuşsal durumların motivasyon, akademik başarı ve mesleğe karşı tutum gibi faktörlere etki ettiği anlaşılmaktadır. Araştırmaya katılan öğretmenlerin bu soruya verdikleri cevaplardan bazıları aşağıda verilmiştir:

\begin{tabular}{|c|c|}
\hline $\begin{array}{l}\text { Kişilik } \\
\text { özellikleri }\end{array}$ & 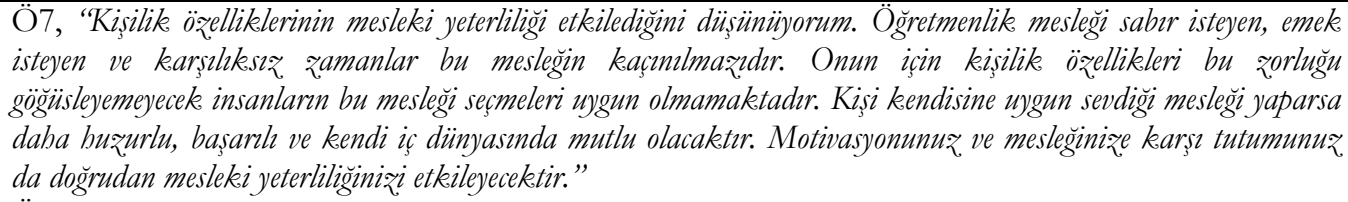 \\
\hline Motivasyon & 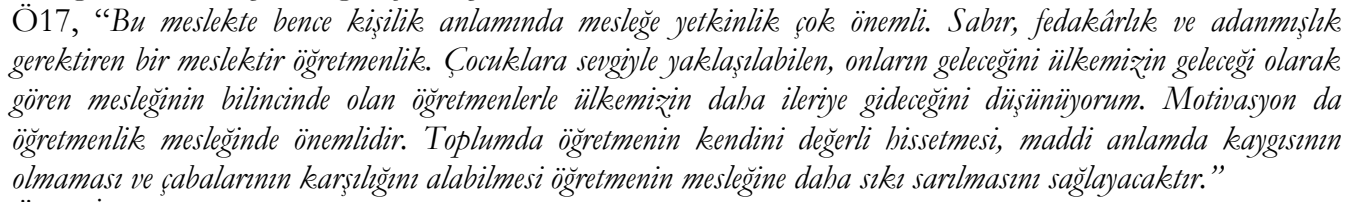 \\
\hline $\begin{array}{l}\text { Akademik } \\
\text { başarı }\end{array}$ & $\begin{array}{l}\text { Ö3, "İsini sevmeyen birinin mesleğinde başarl olması beklenemez. Bizler de işimizi isteyerek severek yaparsak, } \\
\text { ögretimde başaryy yakaları." }\end{array}$ \\
\hline $\begin{array}{l}\text { Mesleğe } \\
\text { karş1 tutum }\end{array}$ & 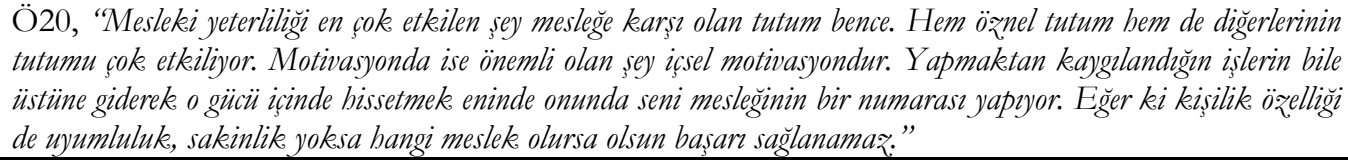 \\
\hline
\end{tabular}

Bu bulgulara göre duyuşsal durumların mesleki yeterliliği kişilik özellikleri, motivasyon, akademik başarı ve mesleğe karşı tutum faktörleri açısından olumlu yönde etkilediği söylenebilir.

\section{Mesleki Gelişimin Mesleki Yeterliliğge Etkisi}

Öğretmenlerin mesleki gelişimin mesleki yeterliliğe etkisine ilişkin görüşlerini almak üzere “Öğretmenlerin mesleki gelişimlerinin (alanı ile ilgili güncel bilgileri/yenilikleri takip etmesi; hizmet içi 
faaliyetlere katılım) mesleki yeterliliklerine olan etkisi hakkındaki görüşleriniz nelerdir?” sorusu yöneltilmiştir. Öğretmenlerin verdikleri cevaplar doğrultusunda oluşturulan model aşağıda yer almaktadır.

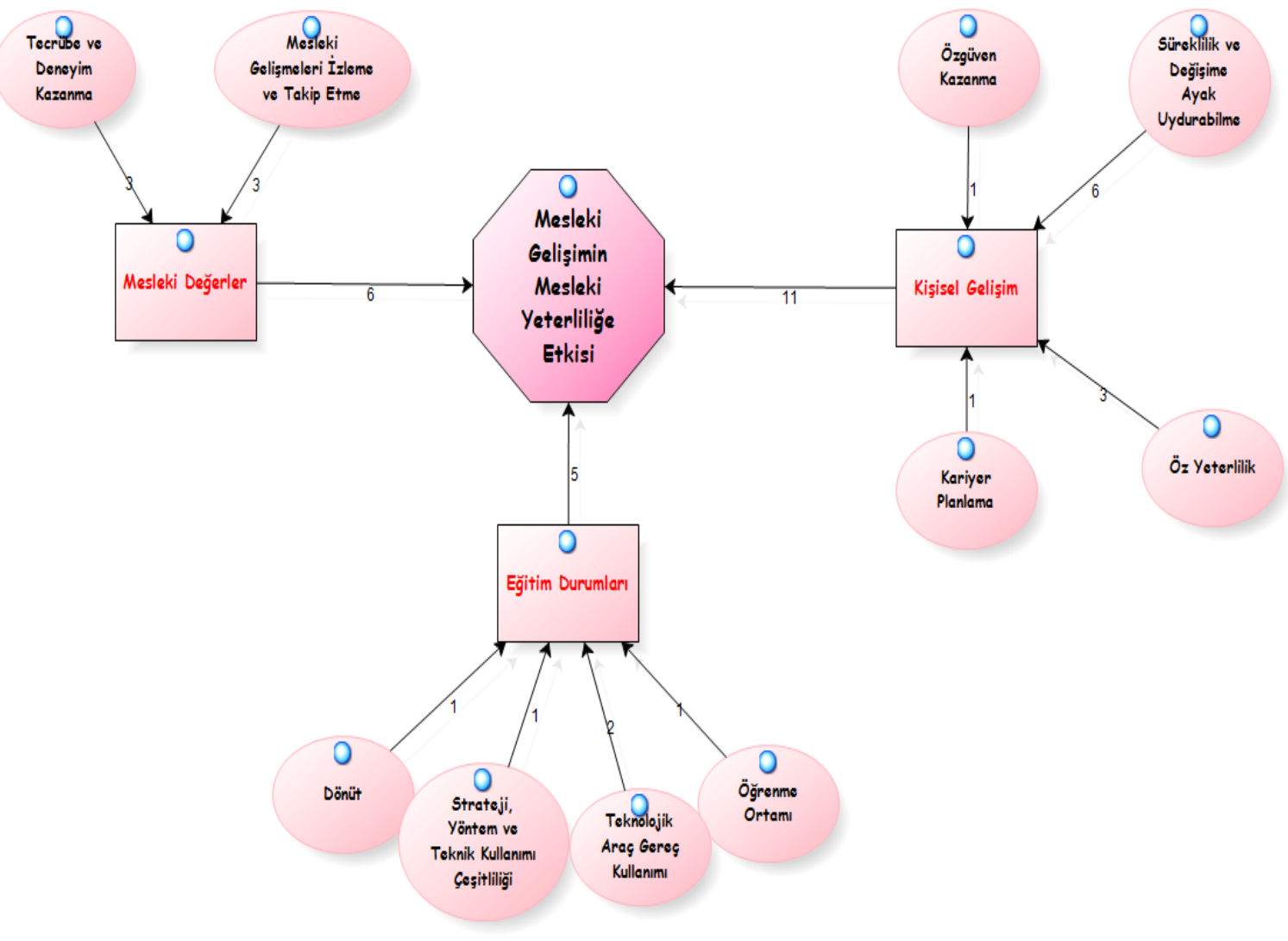

Şekil 6. Mesleki Gelişimin Mesleki Yeterlilige Etkisi

Şekil 6'da görüldüğü üzere öğretmenlerin mesleki gelişimin mesleki yeterliliğe etkisine ilişkin verdikleri cevaplar çeşitlilik göstermektedir. Öğretmenlerin bu soruya verdikleri cevaplar incelendiğinde; kişisel gelişim başlı̆̆ altında süreklilik ve değişime ayak uydurabilme, Öz yeterlilik, kariyer planlama, özgüven kazanma; mesleki değerler başlı̆ı altında tecrübe ve deneyim kazanma, mesleki gelişmeleri izleme ve takip etme ve eğitim durumları başlığı altında teknolojik araç gereç kullanımı, öğrenme ortamı, strateji-yöntemteknik kullanımı çeşitliliği, dönüt gibi faktörlerin mesleki yeterliliğe etki ettiklerini ifade ettikleri görülmüştür. Araştırmaya katılan öğretmenlerin bu soruya verdikleri cevaplardan bazıları aşağıdadır:

\begin{tabular}{|c|c|}
\hline Kişisel gelişim & 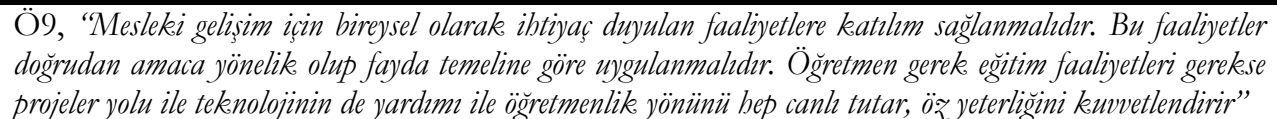 \\
\hline Mesleki değerler & 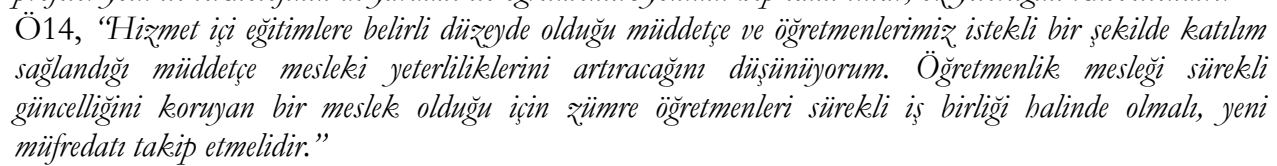 \\
\hline $\begin{array}{l}\text { Eŭitim } \\
\text { durumları }\end{array}$ & 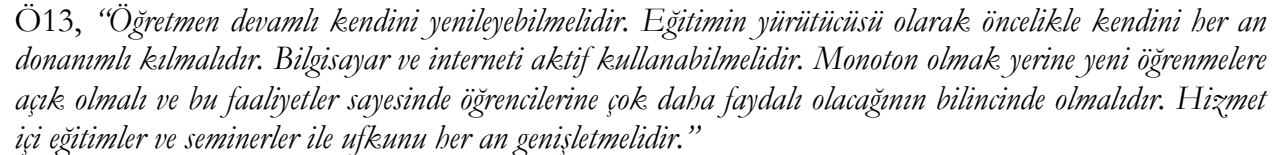 \\
\hline
\end{tabular}

Bu bulgulara göre mesleki gelişimin kişisel gelişim başta olmak üzere, mesleki değerler ve eğitim durumları açısından mesleki yeterliliğe olumlu yönde katkı sunduğu söylenebilir.

\section{Mesleki Yetersizlikler}

Öğretmenlerin mesleki yetersizliklerine ilişkin görüşlerini almak üzere "Kendinizi mesleki anlamda hangi alanlarda yetersiz bulunuyorsunuz?” sorusu yöneltilmiştir. Öğretmenlerin verdikleri cevaplar 
doğrultusunda, bu soruya ilişkin oluşturulan temaya ait kodlar ve frekanslarını gösteren model aşağıda yer almaktadır.

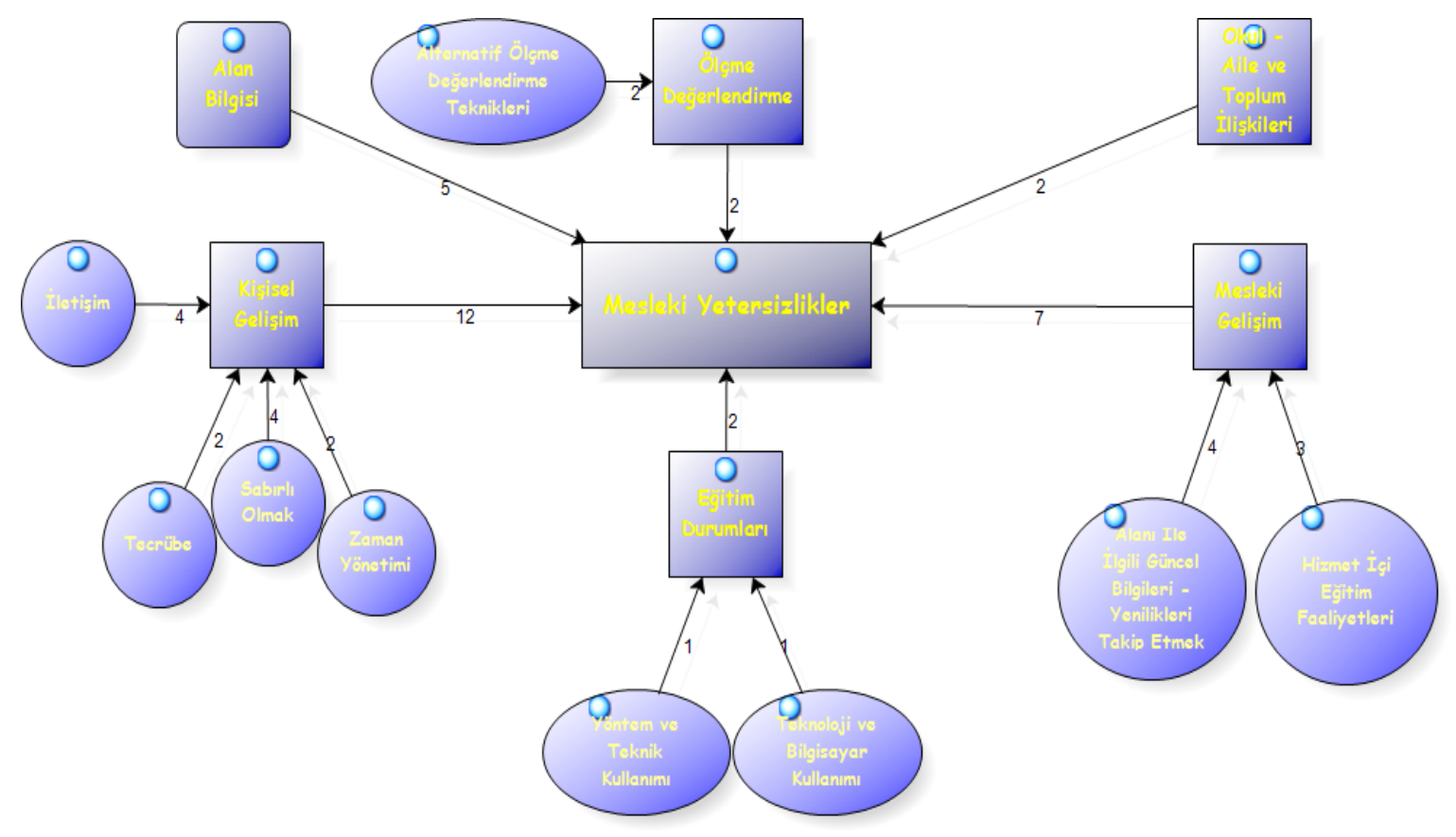

Şekil 7. Mesleki Yetersizlikler

Öğretmenlerin bu temaya ilişkin verdikleri cevaplar incelendiğinde; en çok kişisel gelişim başlı̆̆ altında $(\mathrm{f}=12)$ iletişim, sabırlı olmak, zaman yönetimi, tecrübe eksikliği ve mesleki gelişim başlĭg altında $(\mathrm{f}=7)$ hizmet içi eğitim faaliyetleri, alanı ile ilgili güncel bilgileri-yenilikleri takip etmek faktörlerinde mesleki yetersizlik yaşadıkları görülmektedir. Bunları sırasıyla alan bilgisi; ölçme değerlendirme; okul aile ve toplum ilişkileri ve eğitim durumları başlı̆̆ altında yöntem ve teknik kullanımı ile teknoloji ve bilgisayar kullanımı takip etmektedir. Bu temaya ilişkin katılımcı görüşlerinden bazıları aşağıda verilmiştir:

\begin{tabular}{|c|c|}
\hline Kişisel gelişim & Ö13, "Zaman yönetimi konusunda 40 dakikayı baz̧en planlı kullanamadiğım düsünüyorum." \\
\hline Mesleki gelişim & $\begin{array}{l}\text { Ö6, "Alan olarak değil de kendi branşımla olan güncel yenilikleri sürekli takip edememe açısından } \\
\text { yetersiz buluyorum." }\end{array}$ \\
\hline Alan bilgisi & $\begin{array}{l}\text { Ö16, "Sürekli programlar güncelleniyor. Bazen yeni müfredattaki konulara yönelik etkinlik } \\
\text { tasarlamakta zorlanabiliyorum." }\end{array}$ \\
\hline $\begin{array}{l}\text { Ë̆gitim durumları; } \\
\text { Ölçme } \\
\text { değerlendirme }\end{array}$ & $\begin{array}{l}\text { Ö3, "Teknoloji ve bilgisayar programlar kullanma konusunda eksiklerim olduğunu düsünüyorum. } \\
\text { Ölçme-değerlendirme alaninda kendimi yenilemek ve geliștirmek istiyorum." }\end{array}$ \\
\hline $\begin{array}{l}\text { Okul, aile ve toplum } \\
\text { ilişkileri }\end{array}$ & 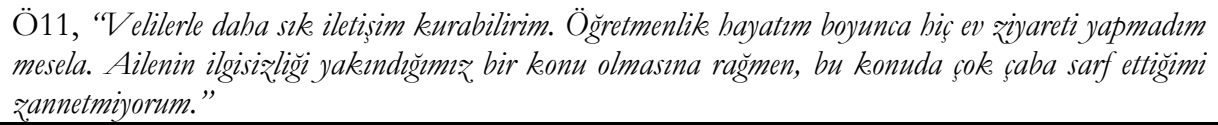 \\
\hline
\end{tabular}

Bu bulgulara göre öğretmenlerin kendilerini özellikle alan bilgisi, iletişim, sabır, alanı ile ilgili güncel bilgileri-yenilikleri takip etme ile hizmet içi eğitim faaliyetleri noktasında yetersiz hissettikleri söylenebilir.

\section{Mesleki Yeterlilik İçin Öneriler}

Öğretmenlerin mesleki yeterliliğe ilişkin önerilerini almak üzere “Öğretmenlerin mesleki yeterliliklerini geliştirebilmelerine yönelik önerileriniz nelerdir?” sorusu yöneltilmiştir. Öğretmenlerin verdikleri cevaplar doğrultusunda, bu soruya ilişkin oluşturulan temaya ait kodlar ve frekansları gösteren model aşağıda yer almaktadır. 


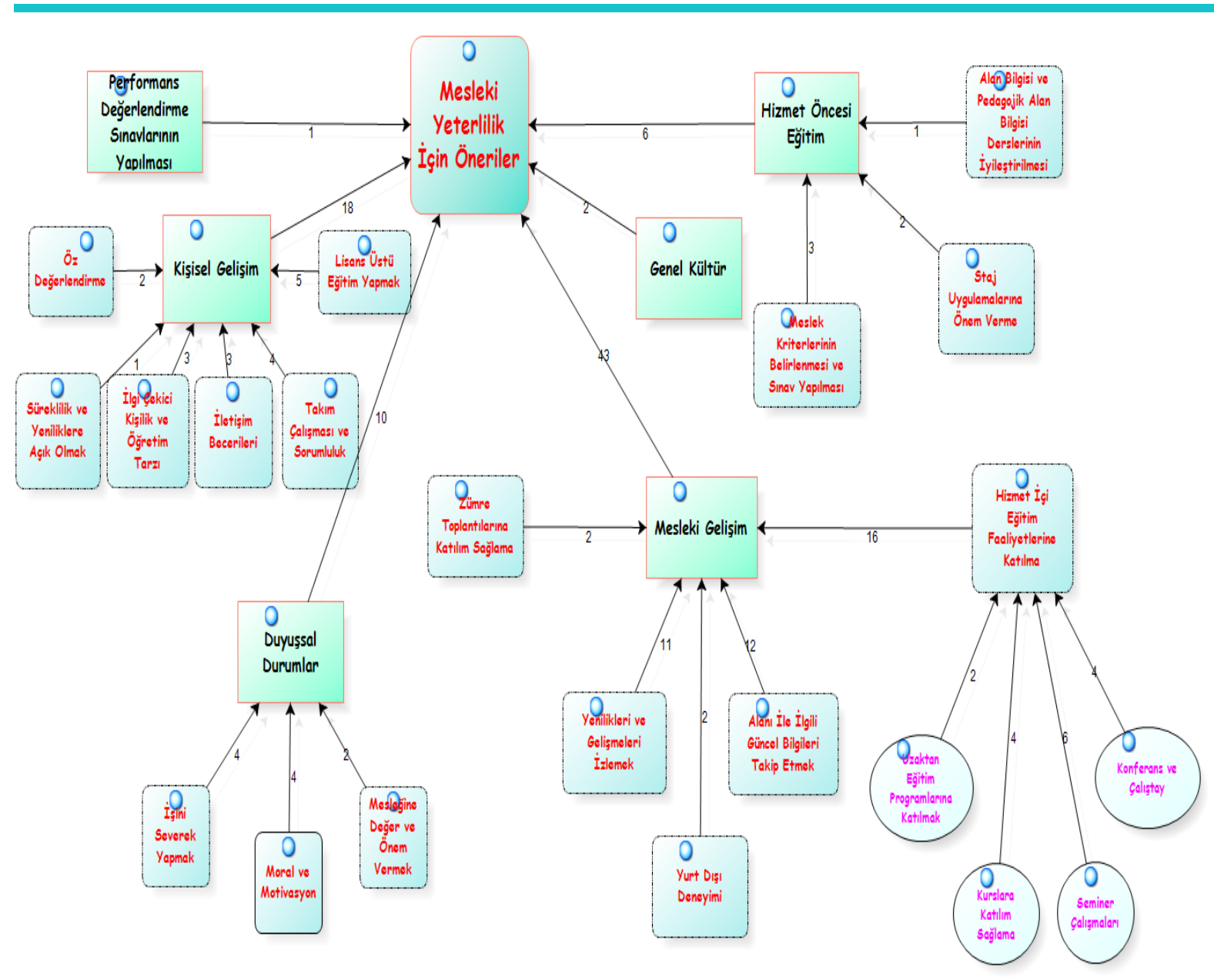

Şekil 8. Mesleki Yeterlilik İ̧in Öneriler

Şekil 8 de görüldüğü üzere öğretmenlerin mesleki yeterlilik için önerileri çeşitlilik göstermektedir. Öğretmenlerin bu soruya verdikleri cevaplar incelendiğinde mesleki gelişim temasının ön plana çıktı̆̆ tespit edilmiştir. Bu başlık altında hizmet içi eğitim faaliyetlerine katılma; alanı ile ilgili güncel bilgileri takip etme, yenilikleri ve gelişmeleri izlemek, yurt dışı deneyimi yaşamak, zümre toplantılarına katılım sağlama alt temalarına ulaşılmıştır. Öneriler noktasında diğer önemli bir faktör kişisel gelişim olmuştur. Kişisel gelişim başlığı altında lisansüstü eğitim yapmak, takım çalışması ve sorumluluk, iletişim becerileri, ilgi çekici kişilik ve öğretim tarzı, süreklilik ve yeniliklere açık olmak, öz değerlendirme kodlarına ulaşılmıştır. Araştırmaya katılan öğretmenlerin bu soruya verdikleri cevaplardan bazıları aşağıdadır:

Mesleki gelişim

Kişisel gelişim

Ö12, “...Şu aşamada ögretmenlerin anlamsız hizmet içi eğitimler yerine alanda başarlh ögretmenlerle işbirliği halinde projeler yapması, birlikte ders işleme çalışmalar yapabilir. Daha kü̧̈ük gruplarla, daha yetkin kişilerle uygulama ăgrrlıkl çalısmalar yapılabilir Seminer dönemlerinde o yul yapulmıs en iyi etkinlikler, çalısmalar uygulamal olarak gösterilebilir. Gelecek ynl okutacaklar sinflara yönelik etkinlik çalısmalar yine seminer döneminde yapulabilir. Yine bu dönemde Avrupa'da ve diğer gelismis ülkelerdeki öğretim yöntem ve teknikleriyle uygulama yapulabilir."

Ö20, "Öncelikle bu konuda gönüllü ve istekli olunmalıdır. Zorla yapılan bir eğitimin çok da faydalı olacağrm düsünmüyorum. Eğitimle ilgili gelismelerin takip edilmesi, ilgili sitelerden faydalanilması, yaymlanan makale ve tezlerin incelenmesi, hižmet içi eğitimlere katılim ve lisansüstü eğitim almaya istekli olunması gerekir."

Ö6, "...Alanlar ile ilgili güncel bilgileri ve yenilikleri takip etmelerinin de önemli olduğunun altın çizmek istiyorum. Bakanlğğn ve yerelde il-ilçe milli eğitim müdürlüklerinin düzenlediŭi hizmet içi eğitim faaliyetlerine katılmann (kurs, seminer, konferans vb.)mesleki yeterliligi gelistirmek acısindan faydası olacaktır. Yüksek Lisans ve doktora yapılarak üniversitedeki akademik ortamdan yararlanmanin kişisel ve mesleki çalışmalarn gelistirmeye fazlasilla artıs olacaktır."

Ö4, "Yeni nesil klasik tarzdaki ders anlatımlarm sevmiyor. Onlar derse katacak, derse karşı ilgisini arttıracak tarzda ögretim tekniklerine odaklanimalı..." 


\begin{tabular}{|c|c|}
\hline & $\begin{array}{l}\text { Ö6, "Ö̈̆retmenlerin öncelikle yaptıklar işi sevmelerini moral ve motivasyonlarm yüksek tutmalarmn öneririm. } \\
\text { Ögrenci ve velileriyle sağgk.h bir iletişim kurarak işin içine onlar da katmalarnm önemli olduğunu ve böylece } \\
\text { mesleki yeterliliklerini gelistirebileceklerini düsünüyorum..." }\end{array}$ \\
\hline $\begin{array}{l}\text { et } \\
\text { i eğitim }\end{array}$ & 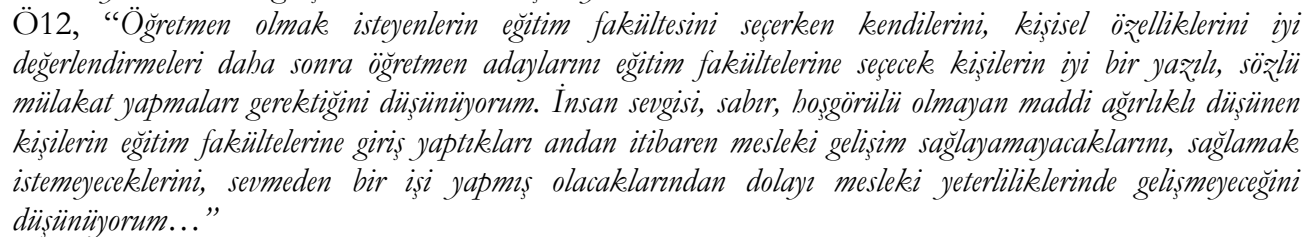 \\
\hline $\begin{array}{l}\text { Genel kültür; } \\
\text { Performans } \\
\text { değerlendirm } \\
\text { sınavlarının } \\
\text { yapılması }\end{array}$ & 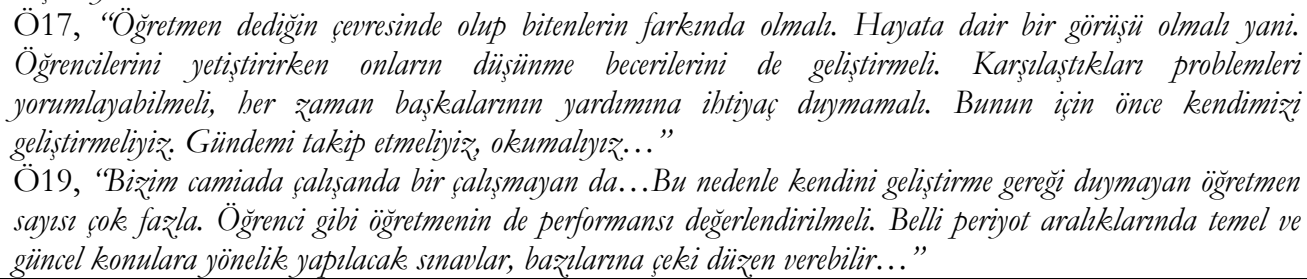 \\
\hline
\end{tabular}

Bu bulgulara göre öğretmenler mesleki yeterlilik için hizmet içi eğitim faaliyetlerine katılma, alanı ile ilgili güncel bilgileri takip etme, yenilikleri ve gelişmeleri izleme, zümre toplantılarına katılım sağlama, yurt dişı deneyim edinme, kişisel gelişim sağlama, işini severek yapma, hizmet öncesi eğitimlerin iyileştirilmesi, genel kültür sahibi olma ve performans değerlendirme sınavlarının yapılması gibi birtakım öneriler getirmişlerdir. $\mathrm{Bu}$ öneriler ışı̆̆ında yapılacak olan çalışmalar ve eğitimlerle mesleki yeterlilik alanında kazanım sağlanacağı düşünülmektedir.

\section{Tartışma, Sonuç ve Öneriler}

Çalışmada öğretmenlerin genel anlamda mesleki yeterliklerini etkileyen faktörler; hizmet öncesi eğitim, mesleğe karşı tutum, okul iklimi, mesleki deneyim, mesleki gelişim, aile ve sosyal çevre ve ekonomik durum olarak belirlenmiştir. Belirlenen bu faktörlerin hangi açılardan mesleki yeterliklere etki ettiğini tespit edebilmek için hem katılımcı öğretmenler hem de ilgili literatürde genel olarak ortaya konan faktörler hakkında katılımcıların görüşlerine başvurulmuştur.

Katılımcılara ilk olarak hizmet öncesi eğitimin mesleki yeterliğe etkisi sorulmuştur. Elde edilen sonuçlar başta pedagojik alan bilgisi olmak üzere, mesleğe ön deneyim kazandırması ve alan bilgisi açısından hizmet öncesi eğitimin önemini ortaya koymuştur. Ayrıca, özgüven, farkındalık ve düşünme becerileri kazandırması bakımından da olumlu etkisi olduğu sonucuna ulaşılmıştır. Hizmet öncesi eğitimin mesleki yeterliğe etkisine ilişkin literatürde benzer sonuçlar yer almaktadır. Sevimel ve Subaş1 (2018) ögretmen adaylarının mesleki yeterliklerini arttırılması bakımından özellikle üniversite eğitiminin ve öğretmenlik etkinlik algılarının oluşturulmasında uygulama deneyimlerinin önemli rolünün altını çizmişlerdir. Can (2015) fen bilgisi öğretmen adaylarının mesleki yeterlik kaynaklarını incelediği çalışmasında, alan bilgisi ve pedagojik alan bilgisinin mesleki yeterliği etkileyen önemli faktörler olduğunu belirtmiştir. Yeung ve Watkins (2000) de benzer şekilde öğretmenlerin yeterlik inançlarının en çok öğretmenlik uygulamalarından etkilendiğini, bunun yanı sıra eğitim çalışmalarının, danışman öğretmenlerin, öğrencilerin, ders ve ders planlarının da yeterlik inançları üzerinde etkili olduğunu saptamışlardır.

Mesleki deneyimin mesleki yeterliğe etkisi incelendiğinde, mesleki deneyimin öğretmenlerin kendilerini mesleki ve kişisel anlamda geliştirmeleri hususunda mesleki yeterliklerini olumlu yönde etkilediği ve öğretim yöntem ve tekniklerini etkili kullanabilme ve sınıf yönetimini sağlama açısından mesleki yeterliklerine katkısı olduğu saptanmıştır. Bandura (1997), meslek deneyimin öz yeterliği etkileyen en önemli kaynak olduğunu ifade etmiştir. İlgili literatürdeki çalışmalarda elde edilen sonuçlar mesleki deneyimin öğretmenlik yeterlik inançlarının en iyi yordayıcısı olduğunu göstermektedir (Morris, 2010; Pajares, 2002; Tschannen-Moran ve Woolfolk Hoy 2007). Bu görüşlerin aksine Shazadi, Khatoon, Aziz ve Hassan (2011) çalışmalarında, yaş ve mesleki deneyimin ortaokul öğretmenlerinin öz yeterlikleri üzerinde anlamlı bir etkisinin olmadığını tespit etmişlerdir. Ancak genel görüş mesleğini icra eden öğretmenler için mesleki deneyimin ve hizmet öncesi eğitimini alan öğretmen adaylan için öğretmenlik deneyiminin mesleki yeterlikler üzerinde olumlu etkisi olduğu yönündedir. Bu görüşü destekler nitelikte Arslan ve Bulut (2015), öğretmen adayları için öğretmenlik uygulamalarının önemli olduğunu, yeni yapılacak programlarda öğretmenlik uygulamalarına daha fazla yer verilmesinin adayların öğretmenlik deneyimlerini artıracağını ifade etmişlerdir. Bununla birlikte söz konusu dersleri düzenlerken öğretmenlere destekleyici gerçek öğrenme-öğretme ortamlarının hazırlanmasına dikkat edilmesi gerektiğini belirtmişlerdir. 
Okul ortamı ve sosyal ilişkilerin mesleki yeterliklere olan etkisine yönelik elde edilen sonuçlar özetlendiğinde, okul ikliminin akademik başarıyı, takım çalışmasını ve sorumluluğu, moral ve motivasyonu arttırdığ1 ve mesleki gelişime olumlu etkisi olduğu görülmektedir. Çalışmada elde edilen bu sonuç, ilgili literatürde elde edilen sonuçlarda rastlanmaması bakımından farklılık göstermekte ve önem arz etmektedir. İlk bakışta duyuşsal durumlar kategorisinde yer alabilecek bir faktör gibi gözükse de okul ikliminin ögretmenlerin mesleki yeterlikleri üzerinde önemli etkisinin olduğu ve ayrı bir çerçevede ele alınması gerektiği yadsınamaz bir gerçektir. Olumlu okul iklimi, yetenekli öğrencilerin yetiştirilmesi ve okul yetkinliğinin arttırlması açısından önemli olduğu gibi öğretmenler ve okul yöneticileri arasındaki sorumluluk ve yeterlik duygusunun geliştirilmesine katkı sağlamaktadır (Özen, 2018).

Duyuşsal durumların mesleki yeterliğe etkisine ilişkin öğretmen görüşleri incelendiğinde, duyuşsal durumların özellikle üretkenlik, sabır ve sorumluluk bilinci gibi kişisel özelliklere olan etkisinin ön plana çıktı̆̆ tespit edilmiştir. Bununla birlikte, motivasyonu, akademik başarıyı ve mesleğe karşı tutumları da etkilediği ulaşılan sonuçlar arasındadır. Literatürde elde edilen bu sonuca benzer sonuçlar yer almaktadır (Arslan ve Bulut, 2015; Oh, 2011; Usher ve Pajares, 2008; Yeung ve Watkins, 2000). Ancak ilgili literatürde, Bandura'nın yeterlik kaynaklanı temel alındığında, psikolojik ve duyuşsal durumların diğer yeterlik kaynaklarına göre daha az etkili olduğuna dair farklı sonuçlara da rastlanmaktadır (Mulholland ve Wallace, 2001; Poulou, 2007).

Mesleki gelişim mesleki yeterliğe olan etkisine ilişkin elde edilen sonuçlar, kişisel gelişim bağlamında süreklilik ve değişime ayak uydurabilme, öz yeterliğin artması ve kariyer planlaması yapabilme açısından mesleki gelişimin önemini ortaya koymuştur. Bununla birlikte tecrübe ve deneyim kazanma, mesleki gelişmeleri izleme ve takip etme ve genel olarak eğitim durumlarını iyileştirme bakımından mesleki gelişimin mesleki yeterliğe etkisi olduğu saptanmıştır. Şüphesiz mesleki gelişimin mesleki yeterliğe etkisinin olması ön görülebilen bir sonuçtur. Bu hususta öğretmenlerin mesleki gelişimlerini nasıl sağlayacakları üzerine odaklanılmalıdır. Can (2019) çalışmasında, öğretmenlerin kişisel, alansal, örgütsel ve öğretimsel çerçevedeki meslekî gelişimlerinin sağlanabilmesi için meslekî gelişimin önündeki engellerin ortadan kaldırllmasının ve öğretmenleri meslekî gelişime teşvik edecek uygulamaların yürürlüğe konmasının gerekliliğine vurgu yapmıştır. Dolayısıyla, öğretmenlerin mesleki gelişimlerinin önündeki engellerin öncelikle tespit edilip, bu doğrultuda hizmet öncesi ve hizmet içi eğitim programlarının düzenlenmesi faydalı olabilir.

Çalışmada katılımcıların mesleki anlamda yaşadıkları yetersizliklere ilişkin görüşleri alınmıştır. Elde edilen sonuçlara göre öğretmenlerin genel olarak kendilerini alan bilgisi, iletişim, sabır, zaman yönetimi, alternatif ölçme teknikleri, yöntem teknikleri kullanma, alanı ile ilgili güncel bilgileri-yenilikleri takip etme ve hizmet içi eğitim faaliyetleri konularında yetersiz hissettikleri söylenebilir. Benzer şekilde ortaokul branş öğretmenlerinin öz yeterlikleri üzerine yaptıkları çalışmada Gökyer ve Bakcak (2018), öğretmenlerin ögrencilerin motivasyonu arttırma, ilgisiz öğrencilerin derse katılımını sağlama, öğrencilere üst düzey düşünme becerileri sağlama, nitelikli etkinlik tasarımı ve soru hazırlama, sınıf kurallarına uyum, istenmeyen öğrenci davranışlarını önleme gibi sınıf yönetimi ve öğrenci katılımına yönelik öz yeterliklerinin düşük düzeyde olduğunu tespit etmişlerdir. Yenen'in (2021) öğretmen adaylarının mesleki beceri ihtiyaçlannı belirlemeye yönelik yaptığı çalışmada, adayların özel gereksinimli öğrencilerin öğretiminde kullanılan ögretim tekniklerine, ölçme ve değerlendirme tekniklerine ve öğretimde bilişim teknolojilerinin kullanımına yönelik becerilerini güçlendiren bir eğitime ihtiyaç duyduklarını tespit etmiştir. Bu sonuçlardan öğretmenlerin hizmet öncesi ve hizmet içi olmak üzere iki farklı boyutta kendilerini yetersiz gördüğü alanlar olduğu söylenebilir. Çünkü alan bilgisi, alternatif ölçme teknikleri, yöntem teknikleri kullanma ve zaman yönetimi gibi faktörler hizmet öncesi alınan eğitimin önemine vurgu yaparken; iletişim, alanı ile ilgili güncel bilgileri-yenilikleri takip etme ve hizmet içi eğitim faaliyetlerine katılım gibi faktörler hizmet içi eğitimin önemine vurgu yapmaktadır. Hizmet öncesi eğitimde dikkat çeken husus alan bilgisi ile pedagojik alan bilgisinin öğretmenlik uygulamaları ile birbirine entegre edilmesidir. Öğretmenlerin üniversite eğitiminde edindikleri bilgileri nasıl işe koşacakları eğitim bilimcilerin sıklıkla üzerinde durdukları konular arasındadır. Diğer bir ifadeyle teori ile pratiğin bir biriyle eş güdümlü olması oldukça önemlidir. Richards (2010), İngilizce öğretmen adaylarının mesleki yeterliklerini incelediği araştırmasında, hizmet öncesinde öğretmenlerin içerik ve pedagojik bilgiyi birleştiremediklerini; ancak içerik ve pedagojinin sentezinin ögretim sürecinde nispeten önemli bir olgu olduğunu ifade etmiştir. Katıllımcıların belirttikleri diğer yetersizlikler öğretmenlerin mesleki gelişimlerine yönelik yaşadıkları sıkıntıları işaret etmektedir. Öğretmenlerin mesleki yeterlilikleriyle ilişkili bir kavram olan öğretmenlerin mesleki gelişimleri üzerine çalışma yürüten Can (2019, s. 1618) öğretmenlerin meslekî gelişimlerinin önündeki engelleri; yasal, 
pedagojik, yönetsel ve toplumsal nedenlere dayandirmaktadr. Özellikle, öğretmen seçme, yetiştirme ve istibdammnn

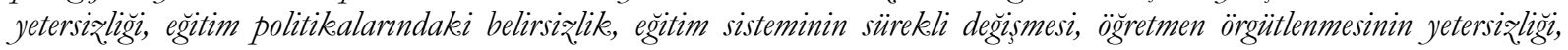
ögretmenlerdeki amas ve motivasyon eksikliği ile ögretmenlerin kariyer gelișimlerinin sağlanamamasın, meslekê gelişimin önündeki engeller olarak tespit etmiştir.

Katılımcılara son olarak mesleki yeterliklerini geliştirebilmeleri için önerileri sorulmuştur. Elde edilen sonuçlar incelendiğinde, öğretmenlerin mesleki yeterlilik için hizmet içi eğitim faaliyetlerine katılma, alanı ile ilgili güncel bilgileri takip etme, yenilikleri ve gelişmeleri izleme, meslektaşlarla iletişim halinde olma, yurt dişı deneyim edinme, kişisel gelişim sağlama, işini severek yapma, hizmet öncesi eğitimlerin iyileştirilmesi, genel kültür sahibi olma ve performans değerlendirme sınavlarının yapılması gibi çeşitli öneriler sundukları tespit edilmiştir. Can'ın (2019) araştırma bulgularına göre öğretmenlerin mesleki gelişimlerinin arttırılması için, yaşam boyu öğrenme ve uzaktan eğitimler aracıllğıyla sürekli gelişim imkânları sağlanmalı, yabancı ülkelerde yürütülen ve iyi örnek teşkil eden mesleki eğitim programlarından yararlanılmalı, bu programlar öğretmenlerin kişisel gelişimlerine, özlük haklarının korunmasına, mesleki anlamda ilerlemelerine katkı sağlamalı, sürdürülebilir bir kariyer planlaması sistemi oluşturulmalı ve öğretmenlerin sempozyum ve kongre gibi akademik etkinliklere katılımları teşvik edilmelidir. Benzer şekilde Aydın (2018) da, eğitim kurumlarının ve öğretmenlerin mesleki yeterlik ihtiyaçlarının giderilebilmesi için hizmet içi eğitim çalışmalarının öğretmenlerin mesleki ihtiyaçlanı doğrultusunda düzenlenmesi gerektiğini ifade etmiştir. Gökyer ve Bakcak (2018) da sınıf yönetiminde etkili unsurlar olan; öğretim yöntem ve tekniklerinden yararlanma, etkili iletişim kurma, etkili zaman yönetimi, değerlendirme ve rehberlik yapma gibi konularda gerek hizmet içinde gerekse hizmet sonrasında öğretmenlerin yetiştirilmelerine yönelik nitelikli seminerler verilmesinin önemine değinmişlerdir. Paralel olarak Elçiçek ve Yaşar (2016), öğretmenlerin ihtiyaç, talep ve görüşleri doğrultusunda okul temelli mesleki gelişim gibi alternatif mesleki gelişim imkânları sağlanarak lider yöneticilerin ve lider öğretmenlerin yetiştirilmesi gerekliliğini savunmuşlardır.

Sonuç olarak, eğitimde kalitenin yakalanabilmesi için öncelikle öğretmen yeterliklerinin yükseltilmesi gerekmektedir. Bu bağlamda, ögretmenlerin sahip olması gereken genel ve özel alan yeterliklerinin günümüz koşullarına göre güncellemesi, öğretmenlerin bu mesleki yeterliklere sahip olup olmadığının hem üniversite eğitimi sırasında hem de hizmet içinde takip edilmesi ve gerekli görüldüğü yerlerde eğitim olanaklarının sunulması, kariyer ve kişisel gelişimlerinin sağlanması faydalı olabilir. Dolayısıyla, ögretmenlerin mesleki yeterliklerini sağlamaya yönelik mesleki gelişim planlamalarının yapılmasına ihtiyaç olduğu söylenebilir. Bu amaçla, mesleki yeterlikleri etkileyen faktörler ve mesleki gelişim ihtiyaçları doğrultusunda eğitim içerikleri oluşturulmalı, uygulanmalı ve değerlendirilmelidir. Bununla birlikte, öğretmenlerin mesleki yeterliklerini arttırmaya için, hizmet öncesinde öğretmen adaylarına, hizmet içinde mesleğe yönelik olmak üzere, kapsamlı ve sürekli mesleki gelişim programları hazırlanarak işe koşulmalıdır.

Araştırmada elde edilen sonuçlar göz önünde bulundurulduğunda şu önerilerde bulunulabilir;

- Öğretmenlerin ihtiyaç ve beklentileri doğrultusunda ilgili kurumlarda ihtiyaç analizleri yapılarak ögretmenlerin mesleki yeterliklerini arttırmaya yönelik eğitimler düzenlenebilir.

- Düzenlenen bu programlara öğretmenlerin katılımlarının sağlanabilmesi için uzaktan eğitim ya da mobil öğrenme olanaklarından yararlanılabilir.

- Düzenlenen bu programlara öğretmenlerle birlikte yöneticilerin de katıllmları sağlanarak okul ortamında sosyal ilişkinlerin geliştirilmesi ve olumlu okul iklimi ortamının oluşturulmasına yönelik etkinlikler düzenlenebilir. Bununla birlikte öğretmenlerin moral ve motivasyonlarını arttırıc1 etkinlikler programlara eklenebilir.

- Öğretmenlerin kendilerini geliştirmelerine yönelik lisansüstü eğitim, kongre, sempozyum, ve yayın gibi faaliyetlere katılmaları için teşvik edici yöntemler geliştirilebilir.

- Söz konusu bu faaliyetler düzenlenirken sivil toplum örgütleri, üniversiteler ve TÜBİTAK gibi kurum ve kuruluşların işbirliğine gidilebilir.

\section{Etik Beyan}

"Öğretmenlerin Mesleki Yeterliklerini Etkileyen Faktörler" isimli bilimsel araştırma projesi dosyası ve ilgili belgeler Nevşehir Hacı Bektaş Veli Üniversitesi Etik Kurulu tarafından incelenmiş olup, çalışmanın gerçekleştirilmesinde etik sakınca bulunmadığına kurul üyeleri tarafından 2020.14.175 tarih ve sayı numarası ile oy birliğiyle karar verilmiştir. Bununla birlikte, çalışmada bilimsel etik ve alıntı kurallarına 
uyulmuş; veriler üzerinde herhangi bir manipülasyona yer verilmemiş ve söz konusu çalşma herhangi bir akademik yayın kuruluşuna değerlendirme için gönderilmemiştir.

\section{Kaynakça}

Akkuzu, N. (2011). Öğretmen adaylarının mesleki yeterlikleri ve mesleki yeterlikleri etkileyen faktörler arasındaki ilişkilerin belirlenmesi: bir yapısal eşitlik modeli örneği. NWS A Education Sciences, 6(4), 2611-2629.

Altnkkurt, Y. ve Ekinci, C. E. (2016). Examining the relationships between occupational professionalism and organizational cynicism of teachers. Educational Process: International Journal, 5(3), 236-253.

Arslan, O. ve Bulut A. (2015, Şubat). Turkish prospective middle grades mathematics teachers' teaching efficacy beliefs and sources of these beliefs. In CERME 9-Ninth Congress of the European Society for Research in Mathematics Education (pp. 1123-1130).

Aydın, İ. (2018). Öğretmenlik kariyer evreleri ve öğretmenlerin meslekî gelişimi. International Journal of Human Sciences, 15(4), 2047-2065.

Bandura, A. (1977). Self-efficacy: toward a unifying theory of behavioural change. Psychological Revien, 84(2), 191-215.

Bandura, A. (1997). Self-efficacy. The exercise of control. New York: W.H. Freeman.

Bolat, O. İ. (2011). Öz yeterlilik ve tükenmişlik ilişkisi: Lider-üye etkileşiminin aracılık etkisi. Ege Akademik Bakıs, 11(2), 255-266.

Bümen, N. T., Ateş, A., Çakar, E., Ural, G. ve Acar, V. (2012). Türkiye bağlamında öğretmenlerin mesleki gelişimi: Sorunlar ve öneriler. Milli Eğitim Dergisi, 42(194), 31-50.

Can, E. (2019). Öğretmenlerin meslekî gelişimleri: Engeller ve öneriler. Eğ̈timde Nitel Araștrmalar Dergisi, 7(4), 16181650. doi: 10.14689 /Issn.2148-2624.1.7c.4s.14m

Can, H. (2015). Sources of teaching efficacy beliefs in pre-service science teachers. Elementary Education Online, 14(1), 358-373. doi: 10.17051 /io.2015.84390

Creswell, J. W. (2015). Nitel arasttrma yöntemleri. M. Bütün ve S. B. Demir (Çev. Ed.). Ankara: Siyasal.

Çapa-Aydın, Y., Uzuntiryaki, E., Temli, Y. ve Tarkın, A. (2013). Özyeterlik Kaynakları Ölçeği'nin Türkçe'ye Uyarlanması. Elementary Education Online, 12(3), 749-758

Darling-Hammond, L. (2006). Powerful teacher education: Lessons from exemplary programs. San Francisco: Jossey-Bass, CA.

Ekiz, D. (2006). Ögrretmen eğitimi ve ögretimde yaklaşımlar. Ankara: Nobel Yayın Dağıtım.

Elçiçek, Z. ve Yaşar, M. (2016). Türkiyede ve dünyada öğretmenlerin mesleki gelişimi. Electronic Journal of Education Sciences, 5(9), 12-19.

Epstein, R. M. ve Hundert, E. M. (2002). Defining and assessing professional competence. Journal of the American Medical Association, 287, 226-235. doi:10.1001/jama.287.2.226

Gökyer, N. ve Bakcak, S. (2018). Ortaokul öğretmenlerinin özyeterlik düzeyleri: Elazığ ili örneği. Turkish Journal of Educational Studies, 5(3), 82-98.

Grossman, P. (1990). The making of a teacher: Teacher knowledge and teacher education. New York, Teachers College Press.

Guskey, T. R. (2007). Results-oriented professional development, İçinde: A. C. Onstein, E. F. Pajak, ve S. B. Ornstein, Contemporary issues in curriculum (s. 334-346). Boston: Pearson Education.

Gültekin, M. (2011). Sosyal bilissel ögrenme kuram. B. Oral (Edt.) Ögrrenme ögretme kuram ve yaklassımlar (s. 101-119). Ankara: Pegem Akademi.

Gürbüz, R., Erdem, E. ve Gülburnu, M. (2013). Sınıf öğretmenlerinin matematik yeterliklerini etkileyen faktörlerin incelenmesi. Abi Evran Üniversitesi Kurşsebir Eğitim Fakültesi Dergisi, 14(2), 255-272.

Heaton, M. (2013). An examination of the relationship between professional learning community variables and teacher self-efficacy. Electronic Theses and Dissertations. Paper 5038.

Henson, R. K. (2002). From adolescent angst to adulthood: Substantive implications and measurementdilemmas in the development of teacher efficacy research. Educational Psychologist, 37, 137-150.

Kaçar, T. ve Beycioğlu, K. (2017). İlköğretim öğretmenlerinin öz yeterlik inançları. İlköğretim Online, 16(4), 1753-1767.

Karacaoğlu, Ö. C. (2008). Öğretmenlerin yeterlik algiları. Yǚüncü Yll Universitesi, Eğitim Fakülttesi Dergisi, 5(1), 70-9.

Kızkapan, O. ve Kırmızıgül, A. S. (2021). Fen laboratuvarı kullanımına yönelik öz yeterlik ölçeği: geçerlik ve güvenirlik çalışması. Trakya Eğitim Dergisi, 11(1), 425-438.

Köksal, N. (2008). Öğretmenlik mesleği genel yeterliklerinin öğretmen, müdür ve bakanlık yetkilileri tarafindan değerlendirilmesi. Pamukkale Üniversitesi Eğitim Fakültesi Dergisi, 23(23), 36-46.

Kulshrestha, A. K. ve Pandey, K. (2013). Teachers training and professional competencies. Voice of Research, 1(4), 2933.

Küçükahmet, L., Değirmencioğlu, C., Uğuzman, E. T., Öksüzoğlu, A. F., Özdemir, İ. E. ve Korkmaz, A. (1999). Ögretmenlik mesleğine giriş. İstanbul: Alkım Yayınevi.

Lee, J. A. (2009). Teachers' sense of efficacy in teaching English, perceived English language proficiency, and attitudes toward the English language: $A$ case of Korean public elementary school teachers. Unpublished doctorate thesis. Ohio State University Department of Philosophy, Ohio.

MEB. (2017). Öğretmenlik Mesleğgi Genel Yeterlikleri. http://oygm.meb.gov.tr/www/ogretmenlik-meslegi-genelyeterlikleri/icerik/39. 
Morris, D. B. (2010). Sources of teaching self-efficacy: A scale validation. (Unpublished doctoral dissertation). Emory University, Atlanta, Georgia.

Mulholland, J. ve Wallace, J. (2001). Teacher induction and elementary science teaching: Enhancing self-efficacy. Teaching and Teacher Education, 17, 243-261.

Oh, S. (2011). Preservice teachers' sense of efficacy and its sources. Psychology, 2(3), 235-240. doi:10.4236/psych.2011.23037.

Özen, H. (2018). A qualitative study of school climate according to teachers' perceptions. Eurasian Journal of Educational Research, 18(74), 81-98.

Pajares, M. F. (2002). Overview of social cognitive theory and of self-efficacy. http://www.emory.edu/EDUCATION/mfp/eff.html

Papadopoulou, V. ve Yirci, R. (2013). Rethinking decentralization in education in terms of administrative problems. Educational Process: International Journal (EDUPIJ), 2(1-2), 7-18.

Patton, M. Q. (2014). Nitel araștırma ve değerlendirme yöntemleri. M. Bütün ve S. B. Demir (Çev. Edt.). Ankara: Pegem Akademi.

Phan, N. T. T. ve Locke, T. (2015). Sources of self-efficacy of Vietnamese EFL teachers: A qualitative study. Teaching and Teacher Education, 52, 73-82. doi:10.1016/j.tate.2015.09.006

Poulou, M. (2007). Personal teaching efficacy and its sources: Student teachers' perceptions. Educational Psychology: An International Journal of Experimental Educational Psychology, 27(2), 191-218. doi:10.1080/01443410601066693

Richards, J. C. (2010). Competence and performance in language teaching. RELC Journal, 41(2), 101-122. doi:10.1177/0033688210372953

Senemoğlu, N. (2013). Gelişsim, ögrenme ve ögretim-kuramdan uygulamaya (23. Bask1). Ankara: Yarg1 Yayınevi.

Sevimel, A. ve Subasi, G. (2018). The factors affecting teacher efficacy perceptions of Turkish pre-service English language teachers. The Journal of Language Teaching and Learning, 8(1), 1-17.

Shazadi, T., Khatoon, S., Aziz, S. ve Hassan, H. (2011). Determining factors affecting teachers' self-efficacy at secondary school level. Language in India, 11(10), 385-395.

Shulman, L. S. (1987). Knowledge and teaching: Foundations of the new reform. Harvard Educational Review, 57(1), 122.

Şahin, E. (2010). Illköğretim simf ögretmenlerinin ögretim stili terciblerinin, cinsiyetlerinin, mesleki kıdemlerinin, özyeterlik algzlarmmn ve ögyönetimli ögrenmeye hažr bulunusluk düzeylerinin mesleki yeterlikleri üzerindeki etkisi (Doktora Tezi). Yıldız Teknik Üniversitesi, Sosyal Bilimler Enstitüsü, İstanbul.

Şişman, M. (2009). Öğretmen yeterlilikleri: Modern bir söylem ve retorik. İnönü üniversitesi Eğitim Fakültesi Dergisi, 10(3), 63-82.

TDK (2020). Yeterlik. https://sozluk.gov.tr/ adresinden erişilmiştir.

Thompson, G. (2016). Japanese high school English teachers' self-efficacy beliefs about teaching English (Doctorate Thesis). School of Cultural and Professional Learning Faculty of Education, Queensland University of Technology, Queensland.

Tschannen-Moran, M. ve Woolfolk Hoy, A. (2007). The differential antecedents of self efficacy beliefs of novice and experienced teachers. Teaching and Teacher Education, 23, 944-956. doi:10.1016/j.tate.2006.05.003

Tschannen-Moran, M., Woolfolk Hoy, A. ve Hoy, W. K. (1998). Teacher efficacy: Its meaning and measure. Review of Educational Research, 68(2), 202-248.

Usher, E. L. ve Pajares, F. (2008). Sources of self-efficacy in school: Critical review of the literature and future directions. Review of Educational Research, 78(4), 751-796. doi:10.3102/0034654308321456

Yenen, E. T. ve Kılınç, H. H. (2018). Öğretmenlerin öğretmenlik mesleği genel yeterliklerine sahip olma düzeylerinin incelenmesi. Uluslararası Türkse Edebiyat Kültür Eg̈itim (TEKE) Dergisi, 7(4), 2767-2787.

Yenen, E. T. (2021). Prospective teachers' professional skill needs: a Q method analysis. Teacher Development, 25(2), 196-214. https://doi.org/10.1080/13664530.2021.1877188

Yeşilyurt, E. (2011). Öğretmen adaylarının öğretmenlik mesleğinin genel yeterliklerine yönelik yeterlik algıları. Türk Eğitim Bilimleri Dergisi, 9(1), 71-100.

Yeung, K. W. ve Watkins, D. (2000). Hong Kong student teachers' personal construction of teaching efficacy. Educational Psychology: An International Journal of Experimental Educational Psychology, 20(2), 213-235. doi:10.1080/713663713

Yıldırım, A. ve Şimşek, H. (2013). Sosyal bilimlerde nitel araştırma yöntemleri. Ankara: Seçkin Yayıncılık.

Yirci, R. (2017). Öğretmen profesyonelliğinin önündeki engeller ve çözüm önerileri. Ahi Evran Üniversitesi Kirşehir Eğitim Fakültesi Dergisi, 18(1), 503-522.

\section{EXTENDED ABSTRACT}

In order to ensure the professional competence development of teachers, determining the factors affecting teacher competencies and developing suggestions for increasing teacher competencies by determining these obstacles are of great importance. When the literature is analyzed, it is seen that teachers' professional competencies are affected due to different reasons, especially the four resource models affecting Bandura's self-efficacy. However, these four resource models that affect the self-efficacy put forward by Bandura can be extended with the participation of teachers from different branches. 
Considering that the studies in the related field are generally quantitative studies, and the limited number of qualitative researches, determining the factors affecting teachers' professional competencies and developing solutions in this context increase the importance of the research.

The purpose of this study is to determine the factors affecting teachers' professional competencies and to develop suggestions for teachers to increase their professional competencies. The research was carried out within the framework of the case study, which is one of the qualitative research models. The case study model offers a holistic and in-depth analysis of a current phenomenon within real life events (Creswell, 2015). The study group of the research consists of 20 volunteer teachers working in different branches in the provinces Aksaray, Kayseri and Nevşehir in the 2019-2020 academic year. Convenience sampling was used to identify the participants.

In the study, a semi-structured interview form was used as a data collection tool. The form developed by the researcher consisted of eight open-ended questions that reveal teachers' thoughts on factors affecting their professional competence. In the process of creating an interview form, the relevant literature was examined and expert opinions were consulted. The data of the research were analyzed by using content analysis method. A computer-aided qualitative data analysis program was used to analyze the obtained data. The concepts extracted from the interview data are presented by dividing themes and codes into frequencies in shapes. In addition, frequent quotations from teachers' views were made to increase the credibility of the research findings. The opinions of the participants were coded as Teacher 1 (Ö1), Teacher 2 (Ö2),...representing the teachers.

Factors affecting teachers' professional competencies in general terms were found as; pre-service education, attitude towards the profession, school climate, professional experience, professional development, family and social environment and economic situation. In order to determine in which aspects these factors affect professional competencies, the opinions of the participants were consulted about the factors that were generally revealed in the related literature. Participants were first asked about the effect of pre-service training on professional competence. The results obtained have demonstrated the importance of pre-service education in terms of knowledge of pedagogical field, pre-service experience and field knowledge. In addition, it is concluded that it has a positive effect in terms of gaining selfconfidence, awareness and thinking skills. When the effect of professional experience on professional competence was examined, it was found that professional experience positively affected the professional competencies of teachers in developing themselves professionally and personally and contributed to their professional competencies in terms of using teaching methods and techniques effectively and providing classroom management. When the results obtained for the impact of school environment and social relations on professional competencies are summarized, it is seen that school climate increases academic success, teamwork and responsibility, morale and motivation and has a positive effect on professional development. When the opinions of teachers about the effect of emotional states on professional competence were examined, it was found out that the effects of emotional states on personal characteristics such as productivity, patience and responsibility awareness came to the fore. The participants were finally asked about their suggestions to improve their professional competencies. When the results obtained are examined, It has been determined that they offer various suggestions such as to participate in in-service training activities for professional competence, to follow up-to-date information about their field, to follow innovations and developments, to communicate with colleagues, to gain experience abroad, to provide personal development, to love their job and to improve the pre-service training, general culture and performance evaluation exams.

As a result, it is important to raise teacher competencies first in order to improve the quality of the education system. In this context, it may be beneficial to update the general and special field competencies that teachers should have in accordance with today's conditions and to improve them with pre-service and in-service trainings, to provide career developments, to determine applicable teacher competence areas and to apply them. Therefore, it can be said that there is a need to make professional development plans to provide teachers' professional competencies. For this purpose, educational contents should be created, implemented and evaluated in line with the factors affecting professional competencies and professional development needs. In addition, comprehensive and continuous professional development programs can be prepared and implemented in order to increase the professional competencies of teachers. 